\title{
Fossil Energy Program Progress Report for February 1978
}

\author{
L. E. McNeese
}




\section{DISCLAIMER}

This report was prepared as an account of work sponsored by an agency of the United States Government. Neither the United States Government nor any agency Thereof, nor any of their employees, makes any warranty, express or implied, or assumes any legal liability or responsibility for the accuracy, completeness, or usefulness of any information, apparatus, product, or process disclosed, or represents that its use would not infringe privately owned rights. Reference herein to any specific commercial product, process, or service by trade name, trademark, manufacturer, or otherwise does not necessarily constitute or imply its endorsement, recommendation, or favoring by the United States Government or any agency thereof. The views and opinions of authors expressed herein do not necessarily state or reflect those of the United States Government or any agency thereof. 


\section{DISCLAIMER}

Portions of this document may be illegible in electronic image products. Images are produced from the best available original document. 
Printed in the United States of America. Available from National Technical Information Service

U.S. Department of Commerce

5285 Port Royal Road, Springfield, Virginia 22161

Price: Printed Copy $\$ 5.25$; Microfiche $\$ 3.00$

This report was prepared as an account of work sponsored by an agency of the United States Government. Neither the United States Government nor any agency thereof, nor any of their employees, contractors, subcontractors, or their employees, makes any warranty, express or implied, nor assumes any legal liability or responsibility for any third party's use or the results of such use of any information, apparatus, product or process disclosed in this report, nor represents that its use by such third party would not-infringe privately owned rights. 
Contract No. W-7405-eng-26

\section{FOSSIL ENERGY PROGRAM \\ L. E. McNeese \\ Program Director}

PROGRESS REPORT FOR FEBRUARY 1978

Date Published - May, 1978

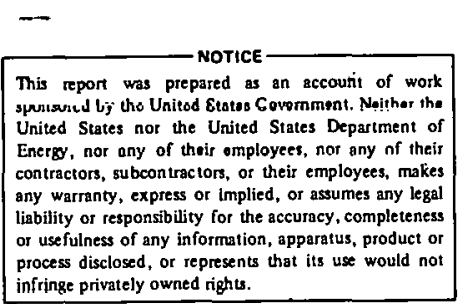

\footnotetext{
OAK RIDGE NATIONAL LABORATORY

Oak Ridge, Tennessee 37830 operated by UNION CARBIDE CORPORATION for the DEPARTMENT OF ENERGY
} 


\section{THIS PAGE}

\section{WAS INTENTIONALLY LEFT BLANK}


CONTENTS

ABSTRACT . . . . . . . . . . . . . . . . . . . . . 1

1. SUMMARY .......................... 1

2. COAL CONVERSION PROCESS DEVELOPMENT . . . . . . . . . . . . 4

2.1 Hydrocarbonization Research . . . . . . . . . . . . . 4

2.2 Experimental Engineering Support of In Situ Gasification Processes . . . . . . . . . . 8

3. MATERIALS ENGINEERING . . . . . . . . . . . . . . . . 13

3.1 Pressure Vessel and Piping Materials . . . . . . . . . . 14

3.2 Inspection Techniques for Wear- and

Process-Resistant Coatings . . . . . . . . . . . . . 14

3. 3 Fossil Energy Welding and Cladding Program . . . . . . . . 15

3.4 Fireside Corrosion of Atmospheric Fluidized Bed

Combustor Tubes... . . . . . . . . . . . . . 16

3.5 Failure Analysis and Prevention ............ 16

4. ALKALI METAL VAPOR TOPPING CYCLE . . . . . . . . . . . 18

4.1 Gas-Fired Potassium Boiler . . . . . . . . . . . 18

5. COAL EQUIPMENT TEST PROGRAM . . . . . . . . . . . . . . . 20

5.1 Critical Equipment for Demonstration Plants . . . . . . . 20

5.2 Coal Feeder Test Program . . . . . . . . . . . . 20

5. 3 Survey of Industrial Capability for Coal

Handling Equipment . . . . . . . . . . . . 21

6. ATMOSPHERIC FLUIDIZED BED COAL COMBUSTOR FOR

COGENERATION (AFB CCC) . . . . . . . . . . . . . . . . 22

6.1 System Design and Assessment . . . . . . . . . . . 22

6.2 Supplemental Studies . . . . . . . . . . . . 22

7. ENGINEEKLNG STUDIES AND TECHNICAL SURPORT . . . . . . . . . . 23

7.1 Process Modeling . . . . . . . . . . . . . . . 23

7.2 Synthetic Fuels Process Research Digest . . . . . . . . . . 24

7.3 Survey of Industrial Coal Conversion Equipment

Capabilities .................. . 24

7.4 Flash Hydropyrolysis ................ 26

7.5 Hot Gas Purification Processes . . . . . . . . . . 26

7.6 State-of-the-Art Review of Heat Recovery Processes . . . . 27

7.7 Assessment of a Moving Bed System for Cleanup of

Raw Gasifier Gas . . . . . . . . . . . . . . . . . 27

7.8 Technical/Economic Assessment of Hydrogen Production

by the Steam/Molten Iron Process . . . . . . . . . . . . . 28

7.9 A Study of Effluent Control Technologies for Hydrocarbon and Carbon Monoxide Emissions from Coal Conversion

Plants . . . . . . . . . . . . . . . . . . 29 
7.10 Environmental Controls for Low-Btu Gasification . . . . . 29

7.11 Support of the Office of Initial Operations (OIO) . . . . . 31

8. PROCESS AND PROGRAM ANALYSIS . . . . . . . . . . . . . . . 32

8.1 Low-Btu Coal Gasification . . . . . . . . . . . . . . 32

8.2 Direct Combustion .. . . . . . . . . . . . . . . 33

8.3 Advanced Power Conversion Systems . . . . . . . . . . . . 34

8.4 In Situ Coal Gasification . . . . . . . . . . . . . . 34

8.5 Coal Beneficiation . . . . . . . . . . . . . 36

8.6 Gas Cleanup Studies . . . . . . . . . . . . . . 36

8.7 HYGAS Modeling ................... . 37

0.8 Liquefaction . . . . . . . . . . . . . . . . 37

8.9 High Btu Gus . . . . . . . . . . . . . . . . . . . . 38

8. 1 U Comparative Cost Estimates of Five Coal Utilisation

Processes ..................... 39

8.11 References for Section 8 ............... . 40

9. FOSSIL ENERGY ENVIRONMENTAL PROJECT . . . . . . . . . . . . . 41

9.1 Stored Solids Study . . . . . . . . . . . . . . . . . 41

9.2 Environmental Monitoring Handbook ............ . 42

9.3 Technical Assistance ... . . . . . . . . . . . 42

9.4 Carryover Activities from FY 1977 . . . . . . . . . . . 42

10. MAGNETIC BENEFICIATION OF DRY PULVERIZED COAL . . . . . . . . 43 10.1 Objective . . . . . . . . . . . . . . . . . 43 10.2 Status Summary ................. 43

11. ATMOSPHERIC FLUIDIZED BED COMBUSTION DEMONSTRATION PLANT . . . 44 11.1 Demonstration Plant Management Support . . . . . . . . . 44 11.2 Technology Assessment . . . . . . . . . . . . . . 44 


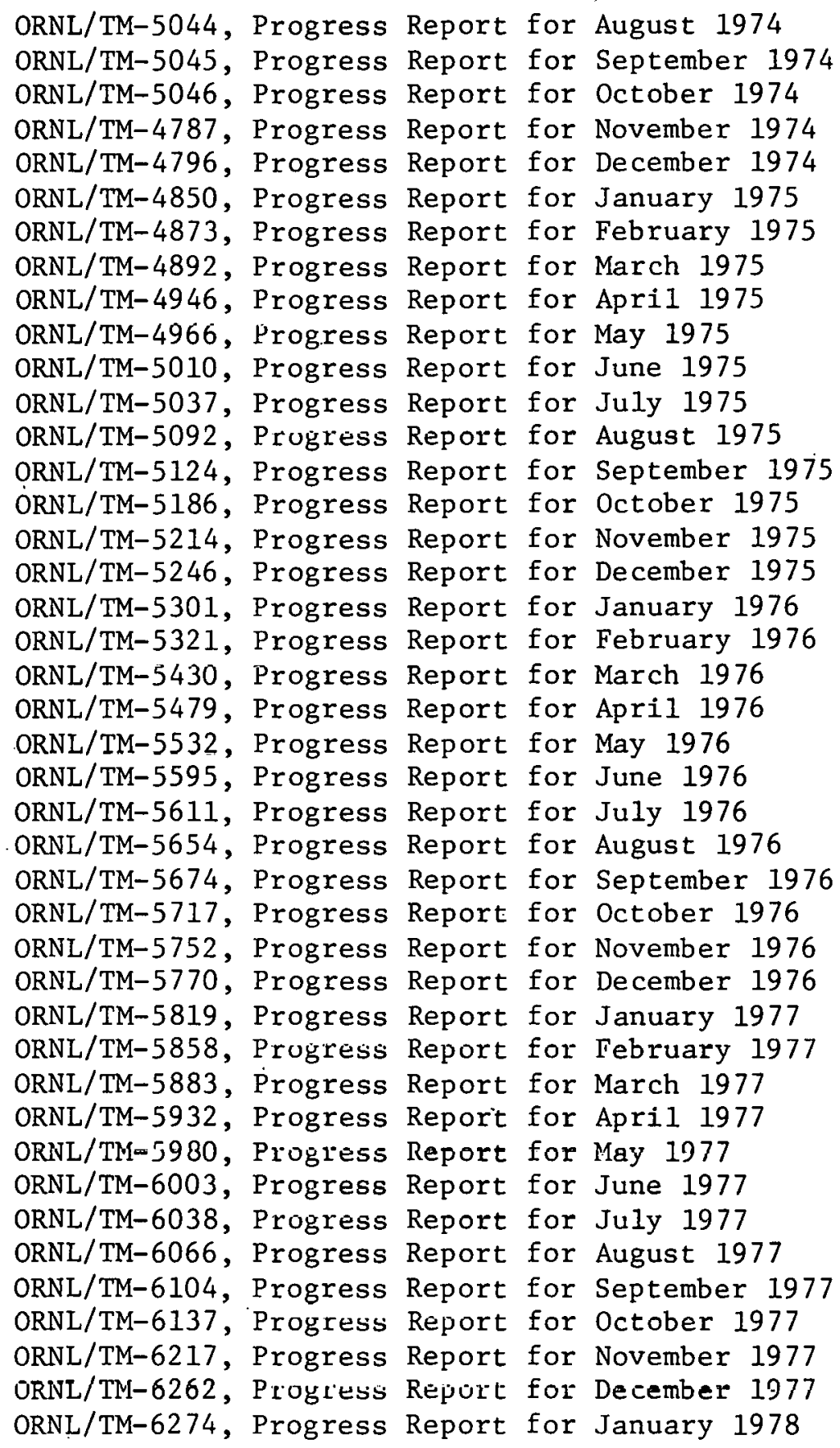




\section{ABSTRACT}

This report - the forty third of a series - is a compendium of monthly progress reports for the ORNL research and development programs that are in support of the increased utilization of coal and other fossil fuel alternatives to oil and gas as sources of clean energy. The projects reported this month include those for coal conversion process development, materials engineering, alkali metal vapor topping cycles, a coal equipment test program, an AFB coal combustor for cogeneration (CCC), engineering and support studies, process and program.assistance, environmental assessment studies, magnetic beneficiation, and AFBC demonstration plant.

\section{Summary}

L. E. McNeese

Highlights of our progress in February are as follows:

- During February we continued the cleanup and sampling of the system after Hydrocarbonization run HC-25. Part of the analytical results have been received and information based on these data are presented.

Preparation of coal feed for run HC-26 has begun. Results from recent scouting tests have been used to establish a procedure for treating the coal feed (Illinois No. 6) with an aqueous solution of $\mathrm{CaO}$ and $\mathrm{Na}_{2} \mathrm{CO}_{3}$ at $80^{\circ} \mathrm{C}$ and atmospheric pressure for $24 \mathrm{hrs}$.

- In support of in situ gasification, block pyrolysis experiment BP2-44 was conducted in which a bituminous coal block was heated to $650^{\circ} \mathrm{C}$ in three steps using a $\mathrm{H}_{2}$ reactor purge gas. This experiment continues a series which investigates effects of $\mathrm{H}_{2}$ on block pyrolysis. Swelling of the block and plastic behavior during pyrolysis were substantially reduced at the higher heating rate of this experiment ( $5 \mathrm{C}^{\circ} / \mathrm{min}$ ) compared with previous experiments at a heating rate of $3 \mathrm{C}^{\circ} / \mathrm{min}$. Design of a pressurized apparatus for block pyrolysis studies has been initiated.

- The fracture toughness of $21 / 4 \mathrm{Cr}-1$ Mo in thick sections suitable for large coal conversion systems is being explored for material in the as-fabricated condition in our pressure vessel and piping materials work. Preparation of a facility for exposure of materials to coal conversion process environments is in progress.

- The first CoCrAlY specimens have been plasma sprayed in our coatings inspection program. We are calibrating our $x$-ray fluorescence system for coating thickness work. Type 304 stalnless steel has been qualified 
for use as a penetrameter material for coating radiography of Alloy 800 substrates. Our thermal probe has been sent out for special miniature electronics fabrication. Additional work toward optimization of penetrant methods on cermet coatings was performed.

- In our welding and cladding program, the first samples of $21 / 4 \mathrm{Cr}-$ 1 Mo steel with a clad overlay of type $320 \mathrm{Cb}$ were prepared by submergered arc welding with an alloy-fortified flux. No fissuring was detected either visually or by dye penetrant inspection.

- Experimental work in our fireside corrosion tests to expose various heat exchanger tubes at the Fluidyne atmospheric fluidized bed combustor continues. Scale on types 304,310 , and 316 stainless steels and Alloy 800 exposed for 1000 and $1500 \mathrm{hr}$ is composed primarily of $\mathrm{Ca}$ compounds and coal ash with minor amounts of iron, nickel, and chrome oxides.

- In our failure prevention and analysis program, ORNL staff members examined the internals of the Rivesville AFBC facility during a shutdown preparatory to metallographic examination of "boat" samples removed from that plant by Foster-Wheeler. None of the observations indicate significant materials problems. Examination of corrosion coupons from the SRC pilot plant at Wilsonville, Alabama is in progress. We are also assisting the pilot plant in developing NDE methods for examining cost austenitic steel pressure vessels within the plant.

- In the gas-fired potassium boiler experiment, $4.5 \mathrm{hrs}$ of stable boiling operation was obtained at power levels up to about $3 \times 10^{6}$ $\mathrm{Btu} / \mathrm{hr}$. A potassium leak occurred at a 2-in. tee where liquid potassium streams from the condenser and the gas separator mix. Work is in progress for repairing the system.

- In the Coal Equipment Test Program, negotiations continued with two DOE demonstration plant contractors and their subcontractors concerning non-disclosure agreements under which information could be obtained for the CETP. Work continued.on the development of equipment questionnaires for use in interviewing equipment manufacturers and identifying potential facilities for testing critical components. In the area of coal feeder testing, the proposed coal feeder development program prepared by Jet Propulsion Laboratory was reviewed, design parameters for a coal feeder test facility were considered, and coal feeder development was reviewed with the development sites. Work continued on the survey of industrial capability for coal handling equipment.

- The request for proposal and the coal combustion performance specifications await final DOE/FE approval in our AFB Coal Combustor for Cogeneration program. A study for determining the market potential for industrial application of the CCC was completed which shows that about $61 \%$ of the energy used by industry could potentially he supplied by CCC systems. Installation of the coal feed system in the fluidized bed cold flow model test facility was completed. 
- In work on process modeling, computer coding was completed for the calculation of cost factors for use in a capital cost estimating program module. Work continued on the collection of costs for various alloys for use in the heat exchanger cost code HDC. A simulation model is being developed for an acid gas treating unit using the methyldiethanolamine absorption process. All of these computer program modules will be transmitted to Purdue and Lehigh for incorporation into their computer programs. Work was started on a detailed implementation plan for installation of the Purdue and Lehigh programs on the ORNL computer system.

- Work continued on the second issue of the Synthetic Fuels Process Research Digest.

- In our work on environmental controls for low-Btu gasification, preliminary estimates of the raw, low-Btu product gas and the aqueous wastes likely to be generated in the gasification of coal by four representative gasifiers have been developed. Contacts have been made with vendor and licensors of acid gas treating processes for obtaining process information.

- Work continued on an evaluation of an in situ coal gasification facility for producing methanol which would then be converted to gasoline via the Mobil-M process. A preliminary overall block flow diagram for the syngas to gasoline part of the facility was completed. Material balance and equipment sizing calculations are continuing. A major design objective is to minimize pressure losses in the raw gas while it is being subjected to various treating processes necessary to prepare it for conversion to methanol in order to minimize energy requirements for compressing the gas to the pressure of the methanol synthesis loop ( 1500 psia).

- In our work on computer modeling of the HYGAS reactor, programming of the IGT kinetic model for slow-rate gasification was completed. Preliminary results compare favorably with those presented in an IGT publication for the low pressure regime. Two limiting case approaches have been selected as a basis for modeling devolatilization phenomena in the HYGAS reactor.

- In the Fossil Energy Environmental Project, coal conversion residue for the COGAS process was received. Plans are continuing for using this and other wastes in lysimeter tests for determining the leaching and transport of materials under representative disposal cond1tions. Work continued on the Environmental Monitoring Handbook and technical assistance was provided to DOE/FE on the Memphis Light, Gas, and Water demonstration project.

- In our work on magnetic beneficiation of dry pulverized coal, exploratory testing of the handling characteristics and magnetic susceptability of coal from a power plant pulverizer was begun.

- Work on the AFBC Demonstration Plant is proceeding at a low level with the technology assessment being the major activity. 


\section{COAL CONVERSION PROCESS DEVELOPMENT}

H. D. Cochran, Jr.

Coal conversion process development activities are carried out in the Chemical Technology Division. This section discusses hydrocarbonization studies in a 20-atm bench-scale facility, and engineering support studies for in situ gasification.

\subsection{Hydrocarbonization Research}

E. L. Youngblood, J. Beams, and J. C. Rose

\subsubsection{Bench-Scale Hydrocarbonization}

Work accomplished. During February we continued the cleanup and sampling of the system after run HC-25. The composition and properties of the coal, char, and oil for run HC-25 are presented. Preparation of coal feed for run $\mathrm{HC}-26$ has begun. Results from recent scouting tests have been used to establish a procedure for treating the Illinois No. 6 coal at atmospheric pressure to reduce the caking tendencies.

Following run $\mathrm{HC}-25$, the top and bottom of the reactor were removed for inspection. A nickel deflector cup located above the draft tube showed severe corrosion. None of the 316 stainless steel components of the reactor showed evidence of corrosion; however, a metallographic examination of the interior of the reactor is planned before the system is reassembled.

Some of the analytical results from run $\mathrm{HC}-25$ have been received. We do not yet have all the data required to calculate oil yields or material balances for the run. Compositions of the Wyodak coal and char for HC-25 are given in Table 2.1. Properties and composition of oil from the cold trap, after being centrifuged to remove most of the water and char, are given in Table 2.2. Properties of the oil from run HC-12, made at $1025^{\circ} \mathrm{F}$ and 300 psig with Wyodak coal, are shown for comparison purposes. The oil from HC-25 has a slightly higher viscosity than that from run HC-12 made at the higher hydrogen pressure. The simulated boiling point curve for oil product from run $\mathrm{HC}-25$ is shown in Fig. 2.1.

For the next run we plan to use Illinois No. 6 coal that has been pretreated at atmospheric pressure. The use of such a pretreatment should be much easier and less expensive than treatments requiring the use of an autoclave. The scouting tests shown in Table 2.3 were performed to investigate treatments that might be used for this purpose. In these tests, mixtures of Illinois No. 6 coal $(-50+170$ mesh $)$, water, and other materials were heated for about 24 hours. Following the treatment the coal was filtered, rinsed with water and vacuum dried. As shown by the Free-Swelling Index results, $\mathrm{CaO}$, char, activated carbon, and $\mathrm{FeCl}_{3}$, and mixtures of these materials eliminated caking under some of the conditions used while 
Table 2.1. Composition of Wyodak coal and char for Run HC-25

\begin{tabular}{lrc}
\hline Composition (\%) & Coal feed & Char \\
\hline Moisture & 9.0 & $<0.05$ \\
Ash & 6.2 & 11.49 \\
Volatile matter & 48.3 & 10.9 \\
C (maf) & 73.0 & 91.5 \\
H (maf) & 5.4 & 3.5 \\
N (maf) & 1.1 & 1.3 \\
S (maf) & 0.5 & 0.3 \\
Btu/lb (maf) & 12,565 & 15,334 \\
\hline
\end{tabular}

lable 2.2. Properties and composition of oil from runs $\mathrm{HC}-25$ and $\mathrm{HC}-12$

\begin{tabular}{lcc}
\hline & $\begin{array}{c}\text { Run HC-25 } \\
\text { Wyodak }\end{array}$ & $\begin{array}{c}\text { Run HC-12 } \\
\text { Wyodak }\end{array}$ \\
\hline Specific gravity & 1.02 & 1.07 \\
Viscnsity (cs) & & \\
at $100^{\circ} \mathrm{F}$ & 36 & 18.4 \\
at $210^{\circ} \mathrm{F}$ & -- & 2.6 \\
& & \\
Composition (\%) & 5.7 & 0.7 \\
Moisture & 0.3 & 80.01 \\
Ash & 84.9 & 7.4 \\
Carbon (maf) & 8.3 & 1.0 \\
Hydrogen (maf) & 1.0 & 0.3 \\
Nitrogen (maf) & 0.4 & 5.9 \\
Sulfur (maf) & 5.4 & \\
0xygen (by difference) & & \\
\hline
\end{tabular}


ORNL DWG 78-602R

SIMULATED BOILING POINT CURVE FOR RUN HC-25

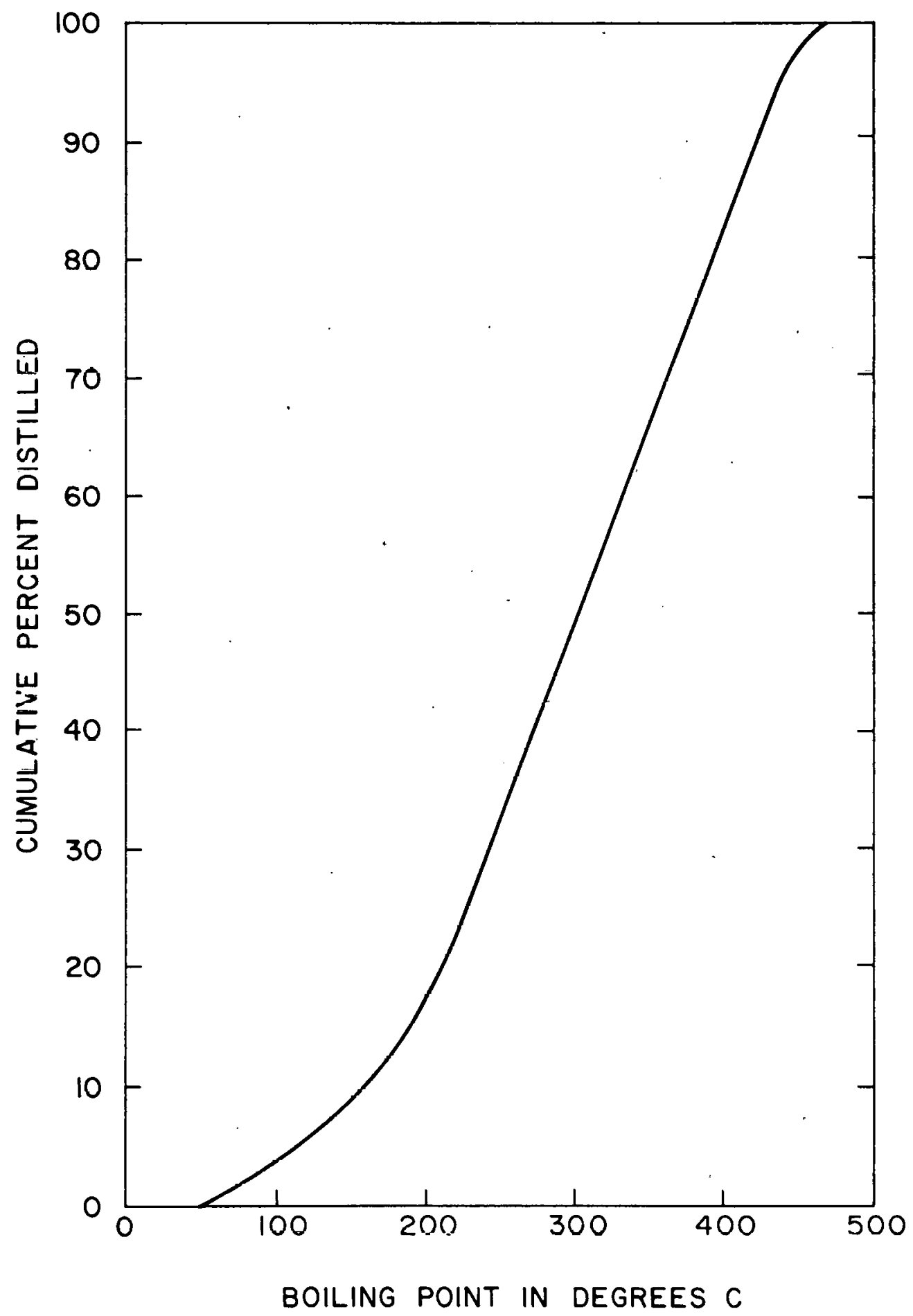

Fig. 2.1. Simulated boiling point curve for oil product from run $\mathrm{HC}-25$. 
Table 2.3. Scouting tests to determine a coal pretreatment method for run $\mathrm{HC}-26$

Samples heated to $80^{\circ} \mathrm{C}$ for 24 hours

\begin{tabular}{|c|c|c|c|c|}
\hline $\begin{array}{l}\text { Sample } \\
\text { number }\end{array}$ & $\begin{array}{l}\text { Amount of } \\
\text { Illinois No. } 6 \text { coal } \\
\text { (g) }\end{array}$ & $\begin{array}{l}\text { Amount of } \\
\text { water } \\
\text { (m1) }\end{array}$ & Chemicals added & $\begin{array}{l}\text { Results of Free- } \\
\text { Swelling Index }\end{array}$ \\
\hline$A-1$ & 15 & 75 & None (control) & $3-1 / 2$ \\
\hline$A-2$ & 15 & 75 & $15 \mathrm{~g} \mathrm{HC}-14 \mathrm{~B}$ char & 1 \\
\hline$A-3$ & 15 & 75 & $30 \mathrm{~g} \mathrm{HC}-14 \mathrm{~B}$ char & 1 \\
\hline$A-4$ & 15 & 75 & $15 \mathrm{~g} \mathrm{HC}-23 \mathrm{char}$ & No caking \\
\hline$A-5$ & 15 & 75 & $30 \mathrm{~g} \mathrm{HC}-23$ char & Ho caking \\
\hline$A-6$ & 15 & 75 & $15 \mathrm{~g} \mathrm{HC}-24$ char & $2-1 / 2$ \\
\hline$A-7$ & 15 & 75 & $30 \mathrm{~g} \mathrm{HC}-24$ char & ilo caking \\
\hline$A-8$ & 25 & 75 & $6 \mathrm{~g} \mathrm{CaO}$ & iNo caking \\
\hline$A-9$ & 25 & 75 & $3 \mathrm{~g} \mathrm{CaO}$ & ito caking \\
\hline$A-10$ & 25 & 75 & 5 y Activated Carbon & . No caking \\
\hline$A-11$ & 25 & 75 & $5 \mathrm{~g} \mathrm{iNaOH}$ & $3-1 / 2$ \\
\hline$A-12$ & 25 & 75 & $2 \mathrm{~g} \mathrm{NaOH}$ & $2-1 / 2$ \\
\hline$A-13$ & 15 & 75 & $15 \mathrm{~g} \mathrm{FeC1}{ }_{3}: 6 \mathrm{H}_{2} \mathrm{O}$ & $1-1 / 2$ \\
\hline$A-14$ & 15 & 75 & $30 \mathrm{~g} \mathrm{Fe}_{2}\left(\mathrm{SO}_{4}\right)_{3}$ & 3 \\
\hline$A-15$ & 15 & 75 & 5. int conc. $\mathrm{H}_{2} \mathrm{SO}_{4}$ & $3-1 / 2$ \\
\hline \multirow[t]{2}{*}{$A-16$} & 15 & 75 & $\begin{array}{l}15 \mathrm{~g} \mathrm{HC}-14 \mathrm{~B} \text { char } \\
\text { (Powdered before mixing) }\end{array}$ & $1-1 / 2$ \\
\hline & \multicolumn{4}{|c|}{ 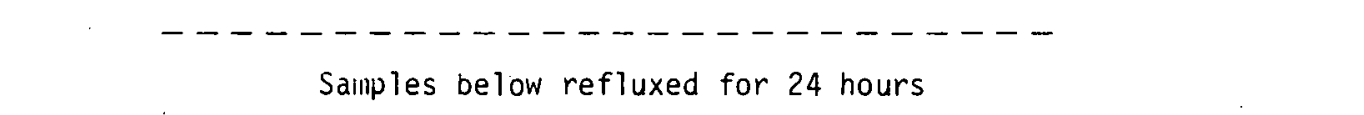 } \\
\hline$B-1$ & 50 & 400 & $1.31 \mathrm{~g} \mathrm{Fe} \mathrm{Cl}_{3} \cdot 6 \mathrm{H}_{2} \mathrm{O}$ & Wo caking, crusty \\
\hline$B-2$ & 50 & 400 & $103 \mathrm{Fe}_{2}\left(5_{4}\right)_{3}$ & $1-1 / 2$ \\
\hline$B-3$ & 50 & 400 & $6.5 \mathrm{~g} \mathrm{CaO}, 5 \mathrm{~g} \mathrm{Na}_{2} \mathrm{CO}_{3}$ & No caking \\
\hline \multicolumn{5}{|c|}{$\begin{array}{c}\text { Samples heated at } 80^{\circ} \mathrm{C} \text { for } 17 \text { hours } \\
\text { S }\end{array}$} \\
\hline$c-1$ & 300 & 1000 & $30 \mathrm{~g} \mathrm{CaO}, 128 \mathrm{~g} \mathrm{Na}_{2} \mathrm{CO}_{3}$ & No caking \\
\hline
\end{tabular}


$\mathrm{Na}_{2} \mathrm{CO}_{3}, \mathrm{NaOH}, \mathrm{Fe}_{2}\left(\mathrm{SO}_{4}\right)_{3}$, and $\mathrm{H}_{2} \mathrm{SO}_{4}$ alone did not. Conditions used in treatment test $\mathrm{C}-1$ using a mixture of $\mathrm{CaO}$ and $\mathrm{Na}_{2} \mathrm{CO}_{3}$ were selected for pretreating the feed for run HC-26. Approximately the same concentration of $\mathrm{CaO}$ is used in this treatment procedure as was used in run $\mathrm{HC}-23$, and the concentration of $\mathrm{Na}_{2} \mathrm{CO}_{3}$ is about the same as that used in $\mathrm{HC}-24$. The $\mathrm{CaO}$ is useful in reducing the caking tendencies of the coal and for reaction with sulfur. The $\mathrm{Na}_{2} \mathrm{CO}_{3}$ is expected to improve the liquid and methane yields and make the char more reactive. Preparations have begun for treating the coal feed for $\mathrm{HC}-26$ using a $\mathrm{CaO}-\mathrm{Na}_{2} \mathrm{CO}_{3}$ treatment at $80^{\circ} \mathrm{C}$ and atmospheric pressure.

Work Forecast. Treatment of Illinois No. 6 coal for run HC-26 will continue. Run $\mathrm{HC}-26$ is planned for near the end of March.

\subsection{Experimental Engiueering Support of In S1ri Gasification Processes}

P. R. Westmoreland and L. S. Dickerson

Coal block pyrolysis experimentation continued during February, supporting modeling and field development of in situ (underground) gasification. Block pyrolysis data are needed for modeling of in situ coal gasification because earlier data described only the pyrolysis of powder samples. By contrast, in situ gasification may react large blocks formed by roof collapse or seam fracturing; possibly it may react a broad seam cross-section. Internal heat and mass transfer resistances are more important, and product yields can change significantly.

In experiments which began at. ORNL in 1975, 6-in.-diam (16 cm) right circular cylinders of subbituminous and bituminous coal have been pyrolyzed by heating the blocks at 0.3-14 $\mathrm{C} / \mathrm{min}$ (surface temperature) from ambient temperature to maximum temperatures of $500-1000^{\circ} \mathrm{C}$. Using an argon or hydrogen purge gas, gas- and vapor-phase reaction products are continuously swept from the reactor. Water, oils, and tars are collected in a watercooled condenser and by filters, and the remaining noncondensible gases are metered and periodically sampled. In many of the experiments, block temperature profiles have been measured by internal thermocouples. These tests are designed to support modeling of field in situ gasification experiments by Laramie Energy Research Center, Lawrence Livermore Laboratory, and Morgantown Energy Research Center (MERC).

Effects of heat and mass transfer resistances have bern nhagrved in both subbituminous and bituminous coal block pyrolysis. Swelling of bituminous coal is markedly reduced in tests at higher heating rates. Such change may result from plasticity distributions within the block, as affected by block temperature profiles. Also at higher heating rates, gas evolution from bituminous coal is increased at the expense of lower char and condensible yields. 


\subsubsection{Recent Experiments and Data}

Block pyrolysis experiment BP2-44 was conducted during February. In an $\mathrm{H}_{2}$ reactor purge gas, a bituminous coal block was heated to $650^{\circ} \mathrm{C}$ in three steps. First, the block was dried thoroughly at $200^{\circ} \mathrm{C}$. Pyrolysis and plastic deformation were initiated in a $5 \mathrm{C}^{\circ} /$ min step to a surface temperature of $500^{\circ}$ which was held until a pyrolysis temperature of $400^{\circ}$ at the center of the block was achieved. Finally, the experiment was finished with a $5 \mathrm{C}^{\circ} / \mathrm{min}$ step to $650^{\circ} \mathrm{C}$ (held until a uniform block temperature was reached). This experiment continues a series of bituminous coal experiments which investigate effects of $\mathrm{H}_{2}$ on block pyrolysis (see Table 2.4). Gas evolution data from BP2-44 are summarized in Table 2.5.

Examination of the BP2-44 char block showed characteristics similar to blocks heated at $3 \mathrm{c} / \mathrm{min}$. Specifically, lava-like folds were observed on the surface crust and little swelling occurred. In addition, the block was divided into three cylindrical segments by two wires wrapped around the block circumference. The segments were joined only within the wire loops, although the crust engulfed the loops as the block swelled. Such behavior would be consistent with the presence of internal plasticity distributions, since a non-sticky solidified crust could be forced outward beyond the loop diameter by a swelling interior.

This behavior contrasts with that of the block in BP2-43 illustrated in Fig. 2.2. In that experiment plastic behavior seemed much more uniform through the block, and temperature was nearly uniform at any time. As a result, all of the block melted and flowed into the bottom of the reactor except for a layer resolidified by contact with the hot reactor wall.

\subsubsection{Future P1ans}

Block pyrolysis experiments at atmospheric pressure will continue during March. The current series of experiments using bituminous coal is nearly complete, and a series using lignite will begin when that coal is received. Analysis and critical evaluation of gas evolution data will continue.

Design of a pressurized apparatus for block pyrolysis will be emphasized during March. To be operated at pressures ranging up to 800 psig, the reactor would be contained within a cold-wall pressure vessel so as to maintain a pressure balance across the heated reactor wall.

Recent results will be described March 22 at a Combined Laboratory and Modeling Working Group Meeting for DOE underground coal gasification development. This meeting will be held at MERC. 
Table 2.4. Summary of experimental conditions for pyrolysis experiments using a hydrogen cover gas and bituminous coal bloci $x^{a}$

\begin{tabular}{|c|c|c|c|c|c|c|c|c|}
\hline \multirow{3}{*}{$\begin{array}{l}\text { Run } \\
\text { number }\end{array}$} & \multirow{3}{*}{$\begin{array}{c}\text { Date }=f \\
\text { run }\end{array}$} & \multirow{3}{*}{$\begin{array}{l}\text { Heatinz } \\
\text { rate } \\
\left(C^{\circ} / \text { (ai) }\right)\end{array}$} & \multirow{3}{*}{$\begin{array}{l}\text { Maximum } \\
\text { temperature } \\
\left({ }^{\circ} \mathrm{C}\right)\end{array}$} & \multirow{3}{*}{$\begin{array}{c}\mathrm{H}_{2} \text { cover gas } \\
\text { flow rate } \\
\text { (std. liter/minl }\end{array}$} & \multicolumn{4}{|c|}{ Coal block } \\
\hline & & & & & \multicolumn{2}{|c|}{ Dinensions $(\mathrm{cm})$} & \multicolumn{2}{|c|}{ Weight } \\
\hline & & & & & Heizh上 & Diameter & $(\mathrm{kg})$ & $(\mathrm{kg} \operatorname{maf})$ \\
\hline BP 2-33 & $8 / 13 / 77$ & 3 & $6: 40$ & 2.90 & 24.0 & 15.7 & 6.133 & 5.811 \\
\hline BP 2-34 & $8 / 31 / 77$ & 3 & 1000 & 2.95 & 17.8 & 15.2 & .4 .564 & 4.323 \\
\hline BP 2-35 & $9 / 21 / 77$ & 3 & 800 & 2.95 & 21.9 & 15.2 & 5.384 & 5.100 \\
\hline BP 2-37 & $10 / 17 ! 77$ & 3 & 8.30 & 3.08 & 18.4 & 15.1 & 4.217 & 3.995 \\
\hline BP 2-38 & $10 / 31 / 77$ & 14 & 870 & 2.90 & 19.7 & 15.4 & 4.658 & 4.413 \\
\hline BP 2-39 & $11 / 14 ! 77$ & 0.3 & 925 & 3.00 & 22.5 & 14.9 & 5.000 & 4.737 \\
\hline BP 2-41 & $12 / 15 / 77$ & 0.3 & 600 & 3.00 & 21.3 & 13.5 & 4.820 & 4.566 \\
\hline$B P 2-42$ & $1 / 10 / 78$ & 0.3 & $930^{k}$ & 2.69 & 15.1 & 13.5 & 3.676 & 3.482 \\
\hline BP 2-43 & $1 / 31 / 78$ & 0.3 & 1032 & $3.07^{c}$ & 17.1 & 15.1 & 3.492 & 3.308 \\
\hline BP 2-44 & $2 / 13 / 78$ & $5^{d}$ & $650^{k}$ & 2.94 & 19.1 & 14.7 & 4.170 & 3.950 \\
\hline
\end{tabular}

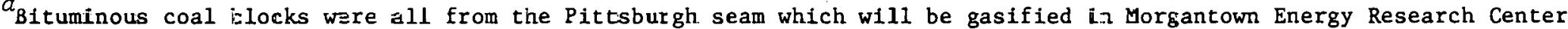
field tests.

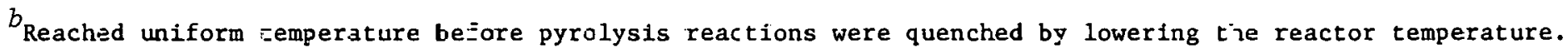

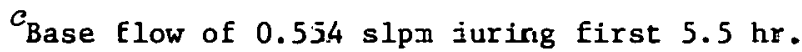

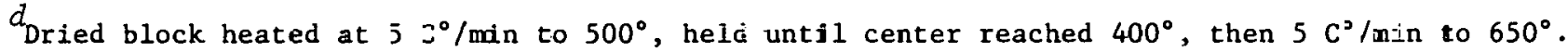


Table 2.5. Summary of preliminary gas evolution data from experiment BP 2-44

(block fyrolysis of bituminous coal to $650^{\circ} \mathrm{C}$ at $5 \mathrm{C}^{\circ} / \mathrm{mln}, \mathrm{H}_{2}$ purge gas).

\begin{tabular}{|c|c|c|c|c|c|c|c|c|}
\hline & Total & $\mathrm{H}_{2}$ & $\mathrm{CH}_{4}$ & $c_{2}^{\prime} s$ & $c_{3}{ }^{\prime} s$ & co & $\mathrm{CO}_{2}$ & $\mathrm{H}_{2} \mathrm{~S}$ \\
\hline \multicolumn{9}{|l|}{ Gas evolution } \\
\hline Volumetric (std. liters) & 530.7 & 327.5 & 102.62 & 43.11 & 9.80 & 25.44 & 13.46 & 8.73 \\
\hline Nornalized (std. $\ell / \mathrm{kg}$ ma $=$ coal) & 134.34 & 82.91 & 25.98 & 10.91 & 2.48 & 6.44 & 3.41 & 2.21 \\
\hline Mass (g) & 251.3 & 29.46 & 74.48 & 56.94 & 18.98 & 31.8 & 26.4 & 13.28 \\
\hline Nornalized ( $g / \mathrm{kg}$ maf $)$ & 63.63 & 7.459 & 18.86 & 14.42 & 4.81 & 8.05 & 6.69 & 3.36 \\
\hline $\begin{array}{l}\text { Average composition of evolved gas } \\
\text { (Vol \%) }\end{array}$ & -- & 61.7 & 19.34 & 8.12 & 1.85 & 4.79 & 2.54 & 1.64 \\
\hline \multicolumn{9}{|l|}{ Elementa1\composition (g) } \\
\hline $\begin{array}{l}\text { Carboz } \\
\text { Hydrozen } \\
\text { Sulfur } \\
\text { Oxygez }\end{array}$ & $\begin{array}{r}138.5 \\
63.0 \\
12.5 \\
37.4\end{array}$ & & & & & & & \\
\hline $\begin{aligned} \text { Gas higier heating value } & (\mathrm{MJj}) \\
& (\mathrm{Btu}) \\
& (\mathrm{Btu} / \mathrm{scf})\end{aligned}$ & $\begin{array}{l}13.64 \\
12930 \\
641\end{array}$ & . & & & & & & \\
\hline $\begin{array}{l}\text { Gas efficiency (btu in gas/beu in } \\
\text { coal) }\end{array}$ & $=9.7 \%$ & & & & & & & \\
\hline
\end{tabular}




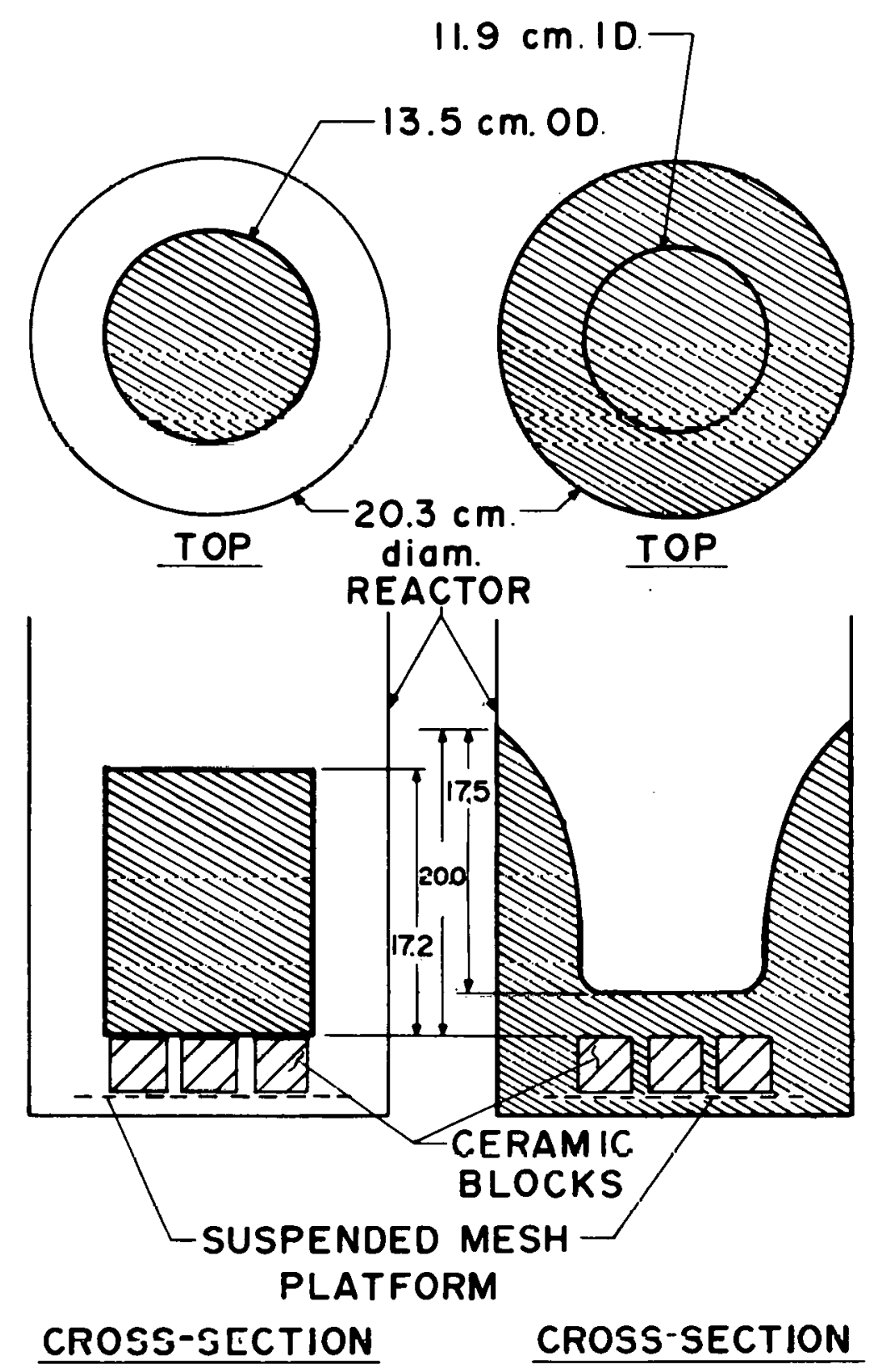

Fig. 2.2. BP2-43 $\left(0.3 \mathrm{C}^{\circ} / \mathrm{min}\right.$ to $\left.1000^{\circ} \mathrm{C}\right)-$ Views of coal block before and after. 


\section{MATERIALS ENGINEERING}

R. T. King

The materials engineering and associated technology reported here are in support of activities directed by the Materials Branch of Plant Initial Operation/Materials and Components office of the Division of Coal Conversion, Fossil Energy. Other related work not funded directly by this division of $\mathrm{DOE} / \mathrm{FE}$ is also included.

\section{Summary}

The fracture toughness of $21 / 4 \mathrm{Cr}-1$ Mo. in thick sections suitable for large coal conversion systems is being explored for material in the as-fabricated condition. Preparation of a facility for exposure of materials to coal conversion process environments is in progress.

The first CoCrAlY specimens have been plasma-sprayed. We are calibrating our $x$-ray fluorescence system for coating thickness work. Type 304 stainless steel has been qualified for use as a penetrameter material for coating radiography of Alloy 800 substrates. Our thermal probe has been sent out for special miniature electronics fabrication. Additional work toward optimization of penetrant methods of cermet coatings was performed.

The first samples of $21 / 4 \mathrm{Cr}-1$ Mo steel with a clad overlay of type $320 \mathrm{Cb}$ were prepared by submerged arc welding with an alloy fortified flux. No fissuring was detected either visually or by dye penetrant inspection.

Experimental work to expose various heat exchanger tubes at the Fluidyne atmospheric fluidized bed combustor continues. Scale on types 304,310 , and 316 stainless steels and Alloy 800 exposed for 1000 and $1500 \mathrm{hrs}$ is comprised primarily of $\mathrm{Ca}$ compounds and coal ash with minor amounts'ot iron, nicke $\perp$, and chrome oxides.

Oak Ridge National Laboratory staff members examined the internals of the Rivesville Atmospheric Fluidized Bed Combustor (AFBC) boiler during a shutdown, preparatory to metallographic examination of "boat" samples removed from that plant by Foster-Wheeler. None of the observations indicate significant problems. Examination of corrosion coupons from the SRC plant at Wilsonville, Alabama is in progress. We are also assisting the plant in developing NDE methods for examinining its cast austenitic steel pressure vessels. 


\subsection{Pressure Vessel and Piping Materials}

W. J. Stelzman and D. A. Canonico

The Charpy and tensile specimens machined from bars which had received different quench rates followed by tempering and stress relief have been received and tested. The Charpy testing and analysis is complete. The analysis of the tensile tests is in progress.

We are preparing additional bars in the DATA TRAK facility to provide specimens with a cooling rate of $0.3 \mathrm{~K}(0.6 \mathrm{R}) / \mathrm{S}$ from $1038^{\circ} \mathrm{C}$ $\left(1900^{\circ} \mathrm{F}\right)$. Some of these bars will be tempered and others tempered and stress relieved. Charpy and tensile specimens will be prepared.

Preparation of the environmental exposure apparatus is in progress; furnaces for the unit are on order.

\section{2 Inspection Techniques for Wear- and Process-Resistant Coatings}

R. W. McClung and G. W. Scott

\subsubsection{Specimens and Standards (G. W. Scott and D. P. Edmonds)}

During initial spraying tests of CoCrAlY powder with our new torch system, the finished coatings were black in color, apparently because of surface oxidation. We wire-brushed the oxide away between spray passes which appears to have solved the problem. We are investigating ways to apply additional shielding gas. This month, we sprayed the first three tensile specimens and one disc specimen that will be machined to make a free-standing layer.

\subsubsection{Penetrating Radiation (G. W. Scott)}

We have picked up the calibration work on our $x$-ray fluorescence (XRF) system, since XRF has been selected as an alternate method of measuring CoCrAlY coating thickness. We have added some additional shielding to allow the use of ${ }^{153} \mathrm{Gd}$ (100-keV gamma) sources.

We performed a basic radiography test to qualify type 304 stainless steel as a penetrameter material for Alloy 800 radiography, in accordance with ASTM Standard E-142. The film density for 304 stainlecs stccl was greater than that for an equal thickness of 1800 at $130 \mathrm{kV}$, and within the allowed $15 \%$ difference.

\subsubsection{Thermal Testing (W. A. Simpson, Jr.)}

An order for a prototype thermal probe has been placed with a local company that specializes in the fabrication of miniature electrical components. A bridge-type detector instrument is being constructed for use with the probe. 


\subsubsection{Surface Inspection Materials (S. D. Snyder)}

This month's efforts were directed toward optimizing the penetrant reversal technique using fluorescent post-emulsified penetrant on the tensile cracked cermet coating. Since these cracks are tighter than those produced by bending, penetrant removal from the cracks by a single emulsification is not adequate to produce good definition of the cracks. It was found that a 2-minute strip-wash followed by 3 or 4 two-minute emulsifications resulted in crack definition as good as or better than the definition of the cracks in the bent specimen. This was seen by comparing the results from this procedure with the results of a 4-minute strip-wash followed by a single 6- or 8-minute emulsification. Apparently, each emulsification step removes a "layer" of penetrant from the cracks in a larger amount than from the surrounding porous areas, making the process more frequency dependent than time dependent. In practice, the inspector would merely observe the surface after each emulsification, wash, and drying step. Obviously, the wider cracks would be seen earlier, after one or two emulsification steps, while the tighter cracks would be seen later, after several additional emulsifications. This, then, provides a qualitative measure of crack sizes.

We have received three tensile-crack specimens with plasma-sprayed coatings of CoCrAlY. Two of the specimens have $0.5 \mathrm{~mm}(0.020 \mathrm{in}$.) thick coatings and one has a $0.025 \mathrm{~mm}$ ( $0.010 \mathrm{in.)}$ thick coating on a IN-800 substrate. They will be cracked for examination during the next reporting period.

\section{3 Fossil Energy Welding and Cladding Program \\ D. P. Edmonds, J. J. Woodhouse, and J. D. Huds on}

We are investigating the effects of cladding conditons on the soundness of type $320 \mathrm{Cb}$ stainless steel cladding deposits. During this. reporting period we have emphasized submerged-arc (SA) cladding of $2.25 \mathrm{Cr}-1$ Mo steel with type $320 \mathrm{Cb}$ stainless steel wire using an alloy fortified flux (Incoflux 6). Cladding deposits have been made at two sets of conditions, with varied oscillation widths. The 2.5 -cm-thick base plates were preheated to $200^{\circ} \mathrm{C}$ before cladding and were postweld heat treated at $677^{\circ} \mathrm{C} \pm 14^{\circ} \mathrm{C}$ for $1 \mathrm{hr}$. Dilutions from base metal varied from 14 to $28 \%$. As one would expect, these dilutions were slightly higher than for deposits made with similar conditions, but without preheat.

Dye-penetrant examination of the surfaces of these deposits revealed no fissures. Also, sectioning of these specimens in the plane normal to the cladding direction revealed no fissures by visual inspection. Specimens are being prepared for metallographic evaluation and side bend testing.

In addition, we have completed a draft report entitled, Cladding of Pressure Vessel. Steels for Fossil Energy Conversion Applications - A Literature Review. Review and r.tearance are in progreec bcfore final publication. 
3.4 Fireside Corrosion of Atmospheric-Fluidized Bed Combustor Tubes

T. G. Godfrey and J. H. DeVan

\subsubsection{F1uidyne 1500-hr Test}

Analysis of the $500-$ and $1500-\mathrm{hr}$ exposure tube samples is continuing. Measurements have been started on tubes 9-C ( 310 stainless stee1), 9-B (Alloy 800), and 8-C (316 stainless steel) which experienced $1000-\mathrm{hr}$ exposure during the 1500-hr test. Semiquantitative spectrochemical analysis of scales from types 304,310 , and 316 stainless steels and Alloy 800 tubes confirmed that the scales are primarily Ca compounds and coal ash with minor amounts of $\mathrm{Fe}, \mathrm{Ni}$, and $\mathrm{Cr}$ oxides. These results indicate that very little protective oxide is being stripped from the tube wa $1 \perp$ by the flaking scale.

\subsubsection{Preparation of Tubes for 3000-hr Test}

Shakedown tests of the FluiDyne AFBC have been successfully completed. The two prototype low-temperature tubes will be removed and returned to ORNL for examination. If they are judged to be sound, the remaining lowtemperature tubes will be similarly prepared and shipped to Fluidyne.

\subsection{Failure Analysis and Prevention}

R. T. King

\subsubsection{Examination of Rivesville Muiti-Ce11 $A \bar{F} B \dot{C}$ (T. G. Godtrey and R. T. King)}

On February 28, 1978, R. T. King and T. G. Godfrey conducted an examination of the Rivesville, West Virginia AFBC plant because of their planned involvement in metallographic examination of "boat" samples cut from the tubes by Foster-Wheeler Corporation. The plant was shut down, the beds were drained, and all internal parts were accessible for inspection. In short, all components, in bed and above bed, appeared as expected with no evidence of erosion, severe corrosion, or fouling. The type 310 stainless steel distributor plates were deformed in the A, $B$, and C cells, but no cracking or tearing was found. Samples of both loose and adherent scales from the various tube bundles were obtained and are being examined.

3.5.2 Examination of Corrosion Coupons from Wilsonville, Alabama Solvent Refined Coal Plant (B. C. Leslie and R. T. King)

A set of about fifty corrosion coupons was received from the Wilsonville, Alabama Solvent Refined Coal Plant. The twelve specimens suspended above the nominal liquid level in the dissolver tank have 
been metallographically examined. Most have a nonuniform, multiphase scale. A photographic summary has been prepared, and microprobe analyses to determine the nature of the scale are in progress. We are beginning to mount the balance of the samples for examination.

\subsubsection{Inspection Assistance to the Solvent Refined Coal Plant, Wilsonville, Alabama (G. W. Scott)}

We completed sawing specimen sections out of the "old" lower head from the SRC dissolver tank. Shop personnel experienced difficulty in placing and holding the saw cuts true because of regions of high hardness in the material. They tended to be in the vicinity of the weld joint between the cylindrical vessel wall and cap sections, but there were other difficult areas in the wall itself. Cutting was ultimately accomplished with a tungsten-carbide-tipped säw blade.

The 1.5-in. thick slab cut from the vessel wall for fabrication of an ultrasonic thickness standard has been radiographed in the direction tangential to the vessel wall (through the 1.5-in. dimensions). No inclusions or other indications corresponding to the "circumferential wire" indications previously reported were found. If such artifacts had been present, the tangential radiograph should have shown a nearly end-on view with high contrast. The slab is now in our ultrasonic laboratory for tests to determine (a) whether it can be penetrated by ultrasound, and (b) what the optimum ultrasonic technique for wall thickness measurement should be. 
4. ALKALI METAL VAPOR TOPPING CYCLES

R. S. Holcomb

\subsection{Gas-Fired Potassium Boiler}

R. S. Holcomb, D. B. Lloyd, and R. H. Guymon

\subsubsection{Objective}

Design, construction, and testing of a full-scale potassium boiler tube bundle and burner module on water and then potassium to determine the performance and operating characteristics.

\subsubsection{Status Summary}

1. The problem of plugging of the condenser vent line was resolved, and the shakedown test was completed.

2. Performance tests were run at burner power levels up to $3.6 \times 10^{6} \mathrm{Btu} / \mathrm{hr}$. The system has been operated at boiling conditions for a total of about $14 \mathrm{hr}$.

3. A potassium leak occurred at a weld on a 2 in. tee in the liquid return line. A crack was found in the weld, and this is believed to have been caused by thermal cycling as a result of a $500-600^{\circ} \mathrm{F}$ temperature difference between the two liquid streams entering the tee.

4. A new tee designed to provide for mixing of the two streams is being fabricated and will be installed. The cooling air provisions on the argon separator have been modified to reduce subcooling of the condensate.

\subsubsection{Plans for Next Month}

The leaking tee will be removed from the system and the new tee will be installed. New electric heaters and thermocouples will be installed on the liquid return line, and the secondary containment will be reinstalled. Operation of the system will be resumed and the endurance test will he initiated.

\subsubsection{Technical Progress}

The potassium was cleancd out of the vent lines downstream of the bubbler, and the excess potassium was blown from the bubbler to the drain tank. After refilling the system, it was operated at several power levels before the off gas line plugged due to a short in a trace heater. 
On February 7, after repairing the short, the system had been. operated for about $41 / 2$ hours at power levels up to $3 \times 10^{6} \mathrm{Btu} / \mathrm{hr}$. when a potassium leak developed. This was first indicated by the smoke detector in the condenser containment enclosure exhaust duct. The system was shut down and the potassium was drained to the drain tank. The drain tank level indicated a loss of 135 pounds of potassium.

The leak occurred at a 2-in. tee where the reflux stream from the center standpipe of the condenser joins the condensate stream from the gas separator. The reflux stream also contained considerable entrainment from the boiler and was at about $1500^{\circ} \mathrm{F}$. In order to prevent potassium carryover in the vent line, the condenser was operating subcooled, and the temperature of the stream from the gas separator was about $900^{\circ} \mathrm{F}$. Cyclic thermal stresses were concluded to be the cause of the failure. A review of the quality assurance documentation indicates no deviation from the requirements.

Although a good portion of the potassium was oxidized and went out the condenser exhaust duct, there was considerable cleanup to be done. This has been completed, the gas separator cooling has been modified, and new heaters have been installed on the vent line.

A mixing tee has been designed, the components have been fabricated, and welding is in progress.

To date we have operated about 14 fours in the stable boiling condition. 


\section{COAL EQUIPMENT TEST PROGRAM}

J. M. Holmes and R. E. MacPhers on

Work under the Coal Equipment Test Program (CETP) is currently divided into three sections:

- Critical Equipment for Demonstration Plants

- Coal Feeder Test Program

- Survey of Industrial Capability for Coal Handling Equipment.

\subsection{Critical Equipment for Demonstration Plants}

J. H. Hulmes, D. E. Reagain, and II. F. llartman

Negotiations continucd with two DOE Demonstration Plant contractors and their subcontractors concerning non-disclosure agreements for use by TRW in the CETP study. Negotiations between Memphis Light, Gas \& Water Division and its subcontractors are currently in progress as are negotiations with the Illinois Coal Gasification Group (ICGG).

A Program Status Review Meeting was conducted at DOE on February 17, 1978. As a result of this meeting, it was decided that TRW would initiate a contract modification to extend the contract schedule through September 30, 1978, and maintain the technical effort at a reduced level through April 1978. This decision was based upon the current status of the nondisclosure agreements and a projected date of May for their compleition. After May, the level of TRW effort will be increased again to a full staff. Work continued on the development of equipment questionnaires for use in interviewing manufacturers and the identiflcation of potent1al facility locations for testing critical components. A material balance has been obtained for the COGAS process using a computer model developed at ORNL. This computer program is currently being completed and will be documented in report form.

\section{2 Coal Feeder Test Program}

J. M. Holmes and B. T. Thompson

Work during the month occurred in three areas: rcviewing the proposed "Coal/Solids Handling and Feed System Development Program," which was prepared by Jet Propulsion Laboratory (JPL); discussing design parameters for a coal feeder test facility; and viewing the bench scale work that had been done by two coal feeder developers. Visits were made to the Jet Propulsion Laboratory and the Lockheed Missiles and Space Company, both in California, to discuss the above work. 
Preparation of criteria for the conceptual design of a pilot scale coal feeder test facility is in progress. Background information has been obtained on the coal feed systems recommended by JPL for further development. Questions concerning design parameters for a coal feeder test facility had been previously submitted to JPL for transmittal to the three feed developers (Foster-Miller, Ingersoll-Rand, and Lockheed). Some answers were obtained during discussions with JPL personnel on February 6 and in the subsequent visit with Lockheed personnel in Sunnyvale, California, on February 7. Lockheed agreed to provide more answers by June 1. None of the developers would have a 5-ton-coal-per-hour pilot feeder ready for delivery (testing) until the latter half of CY 1979.

Feeder test work was viewed at JPL and Lockheed. JPL had a $11 / 2$ in. and $21 / 2$ in. extruder converted to pump plastic-like coal. Lockheed showed their "kinetic extruder" and "ejector" feeder equipment.

Future work will be done to obtain additional answers regarding design parameters for a pilot scale coal feeder test facility. Trips are being arranged to Foster-Miller and Ingersoll-Rand to discuss the test requirements for their coal feeders.

\subsection{Coal Handling/Preparation Equipment Survey}

J. M. Holmes, F. C. Zapp, and O. W. Thomas

A draft work statement was prepared. The purpose of the survey is to determine the types and availability of industrial coal handling, coal preparation and ash/slag removal equipment that will be required for both near-term demonstration and future commercial coal conversion plants. The work statement will be reviewed with DOE personnel before being issued. Reports and literature pertinent to coal conversion plants are being acquired and reviewed to become more familiar with the technology and the types of coal handling/preparation equipment. 


\title{
6. ATMOSPHERIC FLUIDIZED BED COAL COMBUSTOR FOR COGENERATION (AFBCCC)
}

\author{
R. S. Holcomb
}

\section{1 Status Summary}

R. S. Holcomb, R. H. Guymon, and R. L. Graves

The request for proposal and performance specifications for the combustor are currently under final review at DOE/FE.

The application assessment study was completed this month. The first draft of the report was completed at the end of the month and was sent to DOE/FE for review. The major findings of the study are that. aboit $61 \%$ of the energy used by industry could be eupplied by CCC oyotemo. The use of coal-fired cogeneration plants to produce this much of the process heat and generate electricity would result in. a fuel. conversion to coal of $1.5 \mathrm{million}$ bbl/day of oil and $17.8 \mathrm{billion} \mathrm{cu} \mathrm{ft} / \mathrm{day}$ of natural gas combined.

Work is in progress on establishing the requirements and the overall design of the auxiliary equipment for the system. These include heat exchangers, ash handling system, preheater and air compressor. Equipment vendors will be contacted for equipment availability and recommendations for equipment selection. Specifications will be prepared for auxiliary systems or components.

\subsection{Supplemental Studies}

M. E. Lackey and T. G. Codfrcy

Installation of the coal feed system in the fluidized bed cold flow model test facility was completed this month. A preliminary feeding test was run feeding limestone into the empty bed with the in-line capped pipe tlow splitter. The first results indicated a low flow through one of the four feed nozzles, and apparently plugging has nccurred in that feed line. The bed will be emptled, the line unplugged, and the test will be repeated. When uniform $\dot{H}$ low is attained, feeding tests will be run with increasing depth of the fluidized bed.

The corrocion teot program at FluiDyne Engineeriug is belug cuntinued under a DOE/FE contract for an additional $3000 \mathrm{hr}$ exposure time. The test array will continue to include 16 tubes for the CCC program. Eight of the tubes to be installed at the beginning of the $3000 \mathrm{hr}$ test are tubes that were run in the previous $1500 \mathrm{hr}$ of testing. The other 8 tubes are new ones for this test. The tube materials in the test program w1ll continue to be Incoloy 800 and 304,310 and 316 stainless steel.

The new specimen tubes have been prepared at ORNL and are ready to be shipped to FluiDyne. 


\section{ENGINEERING STUDIES AND TECHNICAL SUPPORT}

\section{J. R. McWherter}

Engineering studies and technical support are provided primarily for the DOE/FE Division of Coal Conversion. The effort includes: the development of analytical tools for use in the evaluation of processes and equipment; the technical and economic evaluation and comparison of coal conversion processes and subprocesses on a uniform basis; surveys of the need for coal conversion equipment and the capability of industry to provide such equipment; and studies of the magnitude and control of coal conversion plant emissions.

\subsection{Process Modeling}

R. Salmon, O. L. Culberson, and D. M. Lister

\subsubsection{Contract Objective}

The objective is to assist DOE/FE in its plan for computer analysis and computer support for coal conversion studies. This includes assistance to Purdue and Lehigh Universities in the development of computer programs for this plan. Physical property data are being collected and computerized primarily by Purdue and will be used in support of programs prepared by both universities. Purdue's general design program will aim at material and energy balances, equipment size and costing, plant capacity, and general economics. Lehigh's dynamic simulation programs will address plant design primarily from the standpoint of process performance during transient operations, but can also be used for steadystate conditions. A single flowsheet will be selected to assess the operability and complementary utility of both design programs.

\section{1 .2 Status Summary}

Coding was completed for the calculation of cost factors for use in the capital cost estimating module. The program developed gives coefficients for equations relating the installation costs of concrete, steel, electrical work, etc., to the costs of process equipment of various types as a function of the total cost of each type. These results will be transmitted to Purdue and Lehigh for use in their programs.

Work continued on the collection of costs of various alloys for use in the heat exchanger cost code HDC. Costs of plate, bar stock, forgings, and tubing are being collected from vendors.

Work was started on a detailed implementation plan for the installation of the Purdue and Lehigh programs on the ORNL computer system. The plan will provide a schedule for test runs with the example Purdue and Lchigh flowshecto. 
A simulation model is being developed for an acid gas treating unit using the methyldiethanolamine absorption process. This model is an outgrowth of one used during the Synthoil evaluation, and will include material balance, energy balance, solvent circulation rate, equipment sizing, capital cost estimation, and utilities requirements. The program is now running in preliminary form. When completed, it will be transmitted to Purdue and Lehigh.

Coordination with the MIT Aspen project is one of the objectives of our work. During the month we sent MIT Fortran source decks for five programs developed at ORNL: DEA-1, DEA-2, DEA-3, Benfield-1, and Benfield-2.

Documentation of a number of sparse matrix routines was sent to Purdue and Lehigh for their possible use.

\subsection{Synthetic Fuels Process Research Digest}

F. M. O'Hara, Jr. and R. W. Glass

\subsubsection{Contract Objective}

The objective is to provide continuing technical assistance to DOE/FE by preparing digest reviews of current or potential subjects relating to coal conversion technology.

\section{2 .2 Status Summary}

Articles presently being prepared for the second issue of the Digest are (1) the Consol Synthetic Fuels Process, (2) the SRC-II Process, and (3) Fischer-Tropsch. Drafts of the first two articles have been prepared and advanced copies forwarded to DOE/FE for review; preparation of the fischer-'lropsch article is pending the outcome of the review.

Supplemental to the review is a concurrence on selertion nf artirips for the third issue of the Digest. Suggestions for future articles were collected and forwarded to DOE/FE.

\subsection{Survey of Industrial Coal Conversion Equipment Capabilities}

W. R. Williams, T. M. Andress, W. F. Boudreau, W. A. Bush, W. R. Gambill,

D. W. Hatcher, J. R. Horton, J. P. Meyer, W. R. Reed, C. B. Tolliver

\subsubsection{Contract Objective}

The objective of this project is to conduct surveys of industrial equipment capabilities that will identify the present capability of industry to supply the equipment needed. The project will also determine research and development needs, including lead time requirements, 
for producing equipment of advanced design for the various unit operations of critical importance to the Division of Coal Conversion.

\subsubsection{Status Summary}

All reports on FY 1977 survey activities have been submitted for editing. Publication of the rotating components report is expected in mid-March with the other reports following.

Demonstration plant flowsheets currently available are too elementary to permit determination of equipment operating parameters needed for this survey. Letters of Inquiry concerning equipment operating parameters are being prepared for transmittal to DOE demonstration plant project managers and, through them, to appropriate industry personnel.

HYGAS and Synthoil commercial plant conceptual designs have been reviewed for functional parameters of critical let-down valves. Ft. Lewis SRC pilot plant maintenance and procurement personnel provided information on their let-down valve experience and current valve procurement plans. Suppliers of valve trim for the Ft. Lewis facility were contacted concerning their experience and capabilities to supply valve trim for large valves. A formal survey requesting information on experience and capabilities to supply let-down valves will be mailed to choke-type pressure let-down valve manufacturers in. March.

Review of the previously mentioned conceptual designs provided no information on expansion joints or mechanical connectors for piping systems. However, FY 1977 valve survey work does provide basic information on pipe materials, diameters, and pressure-temperature conditions. A survey form requesting information from expansion joint manufacturers is being prepared. It will be discussed with a local manufacturer of expansion joints before a full survey of industry is undertaken. To date, applicable information on mechanical connectors has been obtained only from the SRC facility.

Personnel working on the lct-down valve, expansiun julnt, and mechanical connector surveys plan to visit a major petrochemical facility in March to discuss high pressure, high temperature applications of such equipment.

Additional cost information was collected and cost correlations are continuing to be reviewed. Shell and tube heat exchanger component prices are being requested from several vendors. These prices will be utilized in a separately funded computer cost estimating code. Results will also be useful to this project.

Pump and heat exchanger operating experience at the Ft. Lewis SRC pilot plant is being reviewed. Pump data confirmed the recommendation of manufacturers made during last year's study that impeller tip speeds must be less than $100 \mathrm{ft} / \mathrm{sec}$ if extended pump life is desired. 
Flowsheets for several processes in which gas expanders are to be used were reviewed to determine whether technology for preventing or allowing ingestion of particulates is anticipated or available. All processes reviewed emphasize particulate removal before the expander, which would imply that special expander designs are not required. However, the availability of the necessary particulate removal equipment is uncertain.

\title{
7.4 Flash Hydropyrolysis
}

\author{
S.P.N. Singh
}

\subsubsection{Cuntract Objective}

The objectives are to perform a preliminary technica $\perp$ and economic assessment of the Cities Service and the Schroeder-Spencer Chemical Company flash hydropyrolysis processes and to determine whether a more detailed engineering evaluation is justified.

\subsubsection{Status Summary}

The draft final report titled "Scoping Study on Two Flash Hydropyrolysis Processes" (ORNL/TM-6265) was approved by DOE. The draft report is currently undergoing technical editing in preparation for publication in final form.

Copies of the draft report have been sent to the two process proponents (Lities service Kesearch and Developmenc Company and Plufessur W. C. Schroeder) for their review and comments. The proponents were requested to submit the1r comments by February 17, 1978. A written response is expected from Cities Service Research and Development Company. As yet, no response has been received from Professor W. C. Schroeder.

\subsection{Hot Gas.Purification Frocesses}

M. S. Edwards and J. P. Meyer

\subsubsection{Contract Objective}

The objective of this project is to investigate the present stateof-the-art hot gas cleanup processes. The application of most interest is the removal of contaminants from coal-derived fuel gas prior to firing combined cycle turbines.

In thie work, a survey of the availahle and develnpment.al processes for the removal at high temperature of various contaminant materials (particulate, sulfur, nitrogen, and alkali metal compounds) has been conducted. Based on the data obtained in this work, from a variety of 
sources, an analysis has been performed to evaluate the performance of a number of potential cleanup processes in light of the overall system needs.

\section{5 .2 Status Summary}

The final report, ORNL/TM-6178, A Survey of. Processes for High Temperature - High Pressure Gas Purification, which includes a review of the available systems for the removal of particulates and sulfur and nitrogen compounds to levels compatible with high temperature - high pressure turbine operation has been approved by DOE and is currently in editing.

\subsection{State-of-the-Art Review of Heat Recovery Processes' W. R. Gambill and W. R. Reed}

\subsubsection{Contract Objective.}

The objective of this review is to survey, appraise, and catalog the processes for heat recovery which industry offers or plans to offer or may logically be expected to offer. These processes will be applicable to the recovery of heat in process streams from primary exothermic coal conversion and combustion process steps. Simple unaugmented application of conventional heat transfer equipment will not be included. The review will distinguish between presently installable technology, near term developable technology, and future prospects. Consideration will be given to possible transfer of technology from other industries.

\subsubsection{Status Summary}

Minor revisions and corrections were made to the draft report describing this study (ORNL/TM-6222). At the suggestion of DOE, two additions to the report were made. One concerns the potential application of transfer line exchangers to quenching the gas stream from a flash hydropyrolysis reactor, and the other a description of experience with waste heat boilers in coal gasification and similar services.

The draft report will be sent to cditing by the end of February.

7.7 Assessment of a Moving Bed System for Cleanup of Raw Gasifier Gas

R. W. Glass and W. R. Gambill

\subsubsection{Contract Objective}

The objective is to evaluate the feasibility of a proposed moving bed system for removal of sulfur and particulates from raw gasifier gas. 
The assessment considers two basic hot gas treatment systems, with each system specifically addressing sulfur and particulate removal. The reference system incorporates a panel filter for dust removal and fixed bed adsorber/regenerator units. The project system incorporates a moving bed filter/adsorber unit, with fluid bed regeneration of the recycled filter/adsorber media. Both systems produce high pressure steam (waste heat boiler) from the regeneration off-gases. The assessment includes simple equipment flowsheets and material balances for both systems, and comparative economics are developed.

\subsubsection{Status Summary}

Minor revisions and corrections were made to the draft report describing this evaluation (ORNL/TM-6223).

A review was made of IGT attribution data for hematite-chromias111ca and hematite-magnesia-silica, relative to siderite $\left(\mathrm{FeCO}_{3}\right)$ and obtained from ball-tumbler and fluidized-bed tests. It was concluded that these data do not seem helpful for estimating attrition rates for the moving-bed sorbent (higher silica and lower iron) chosen for the assessment. report.

Efforts are continuing to resolve other DOE comments on the draft

7.8 Technical/Economic Assessment of Hydrogen Production by the Steam/Molten Iron Process

R. W. Glas3 and L. Seglin*

\section{8 .1 Contract Objective}

The objective is to determine whether there is sufficient incentive to develop the subject process for production of hydrogen from coal: The project considers specifically the comparison of the subject process (a molten-iron/steam concept) to the more conventional concepts employed in the Koppers-l'otzek and Bi-Gas processes. All three processes are considered as part of an overall integrated SRC-II system. Process flowsheets, system costs, and product distributions will be described for each case and comparative economics developed. A development program for bringing the molten-iron process to the state of commercial availability will be addressed.

\footnotetext{
Consultant
} 


\subsubsection{Status Summary}

A progress review meeting was held at ORNL on December 12 with DOE/FE project manager Dr. T. Simpson. The final report draft was reviewed again, and discussions to the effect of rescoping the project study were initiated by Dr. Simpson. The effect of such changes are undergoing further consideration, and final processing of the report will await the outcome of these considerations.

7.9 A Study of Effluent Control Technologies for Hydrocarbon and Carbon Monoxide Emissions from Coal Conversion Plants

J. Fisher and G. R. Peterson

\subsubsection{Contract Objective}

The objective of this project is to provide a technical and economic comparison of processes available for the control of gaseous hydrocarbon (HC) and carbon monoxide ( $\mathrm{CO}$ ) emissions. The Lurgi gasification process is considered as the reference emission source, and comparisons of control technologies consider incineration as the reference control system. This project is supported and directed by the DOE Division of Environmental Control Technology.

\subsubsection{Status Summary}

Technical and economic studies were completed and the results were transmitted to DOE in draft form on December 20, 1977. The results indicate that incineration in a coal-fired boiler is the least expensive of the methods considered.

Work continued on the preparation of the final draft report on the project. It is expected that the draft will be ready for DOE review by the end of February 1978.

\subsection{Environmental Controls for Low-Btu Gasification}

S.P.N. Singh, M. S. Edwards, J. F. Fisher, G. R. Peterson, and R. Salmon

\subsubsection{Contract Objective}

The objective of this project is to evaluate the various environmental control processes that might be used in connection with low-Btu gasification facilities and to determine the economic tradeoffs for various processes and levels of control. 
The project is divided into two phases: Phase I consists of Tasks 1 through 4 of the work statement, and covers the preparation of a detailed work plan and the selection of gasification and environmental control processes for use in the study. Phase II consists of Tasks 6 through 8 in the work statement, and covers the collection and analysis of technical and economic data on the various environmental control processes and the preparation and analysis of flowsheets showing overall systems of environmental control processes used with various gasifiers.

\subsection{0 .2 Status Summary}

Preliminary estimates of the raw, low-Btu product gas and the aqueous wastes 11 kely to be generated in the gasification of coal by four representative gasifiers have been developed. This information will be used to obtain process engineering information regarding the acid gas treating and waste water treating processes from the vendors or licensors of these processes. The information obtained from the process vendors or licensors will be used to develop the costs and the process characteristics of the 25 environmental control processes delineated in Task 2. The 25 processes referred to above were summarized in a letter to DOE/PCSD dated January 18, 1978.

Initial contacts (by telephone followed by a letter) have been made with vendors and licensors of acid gas treating processes. The vendors' responses to our request for process information regarding their processes have been mixed. The responses range from a willingness to provide nonproprietary engineering information on a no-charge basis to an unwillingness to provide any intormation without payment of engineering costs and execution of confidentiality agreements. Where vendor information cannot be obtained, the open literature will be used to develop costs and process characteristics.

Woodall-Duckham (USA) Limited (W-D) has indicated a considerable interest in contracting to supply design and cost information on the raw gas cleanup, sulfur recovery and tail gas treating processes. The package would include information on capital and operating costs, utility requirements, and process limitations. W-D also indicated that they would have no difficulty obtaining process information on the various gas treating processes (both proprietary and non-proprietary), and they would provide rough material balances for the acid gas treating processes. The approximate cost of this service is being determined.

The decontamination duties of each of the water treatment steps within an overall process sequence have been estimated. These process duties will be used to obtain engineering information regarding the water treating processes from the various process vendors or licensors. Alternate disposal techniques for the waste sludges from biological treatment of the waste water and the determination of the minimum levels of waste treatment necessary to permit water reuse in the gasification process are also being determined. 


\subsubsection{Open Items}

We have not yet received written approval from DOE/PCSD to proceed with Phase II of the study, as required by the project work statement. However, verbal approval to proceed with Phase II was given at the December 7, 1977 meeting, with written confirmation to follow.

\subsection{Support of the Office of Initial Operations (OIO)}

B. Niemann, J. F. Fisher, H. F. Harman, and W. R. Reed

\subsubsection{Contract Objectives}

The objectives of this project are: (1) to perform rapid reaction reviews and analyses of documents provided by DOE on coal conversion demonstration plant projects with appropriate follow-up as requested; (2) to conduct requested evaluations in areas which include considerations of start-up, safety, environmental pollution, maintainability, and reliability; and (3) to develop guidelines for the preparation of safety, operation, and maintenance manuals.

\subsection{1 .2 Status Summary}

No review requests were received during the month of February.

Specific personnel within the ORNL Program Divisions and UCC-ND Engineering have been designated to serve as contacts for the review effort. Manpower availability will be addressed at the time of the request.

A Coal Conversion Expertise Directory of Personnel has been prepared and distributed which contains the names of 136 individuals in the Oak Ridge area that have coal conversion and utilization expertise.

A draft set of generic checklists by the main functional areas (operability, start-up, rellabllity, maintainability, safety, and pollution control) has been completed. These draft checklists will be issued for internal comment.

The emphasis of present work is on developing specific design checklists that are applicable to the specific process areas of coal conversion plants. 


\section{PROCESS AND PROGRAM ANALYSIS}

J. R. McWherter

Process and program analysis studies are being conducted for the Office of Engineering Economics and Standards of the DOE Division of Program Control and Support. This effort includes research studies on most of the coal conversion and utilization processes. The program ubjective is to provide, on a consistent basis, technical and economic evaluations of competing processes and systems for coal conversion and utilization.

\subsection{Low Beu Coal Gasification}

H. F. Hartman and J.P. Belk

\subsubsection{Contract Objectives}

The objectives of this study are to survey the low Btu coal gasification processes, select the most promising processes, and provide technical and economic information on the competing processes.

\subsubsection{Status Summary}

Work continued on finalizing the September 1977 draft report. Sections describing 21 low and medium Btu coal gasification processes are being revised based on suggestions by process proponents who reviewed the draft report. Some additional material is being incorporated into the process description sections and other parts of the report. The report sections are being restructured into an arrangement more suited to a potential user. Two volumes are being planned. The first volume will have the following sections.

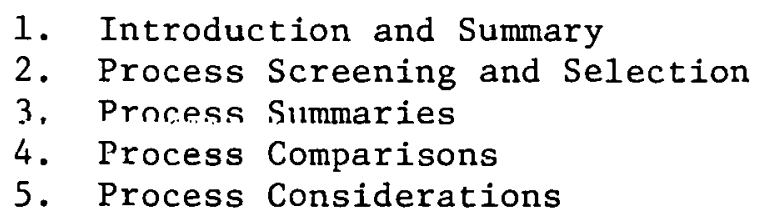

The second (appendix) volume will contain "process data" and will describe the 21. processes of most interest. Parallel work is proceeding on revision and restructuring of material for both volumes. Most of the work required to prepare a revised draft report for DOE review is expected to be completed during March 1978. 


\subsection{Direct Combustion}

E. C. Fox and T. D. Anderson

\subsubsection{Contract Objectives}

The purpose of this study program is to assist DOE/FE in their effort to develop a National strategy to increase the near-term use of coal through direct combustion; the applications of interest in this study are the small-to-moderate industrial user and the large residential/commercial user. The following objectives will be accomplished:

1. Identify and quantify the important factors restricting the use of coal in the sectors of interest.

2. Evaluate potential technological and institutional solutions to the problems identified in (1) above.

3. Make recommendations to DOE/FE relative to the most promising approaches to increasing the near-term use of coal.

\subsubsection{Status Summary}

Work is continuing on Phase 2 of the contract objectives. Capital costs and operating parameters are being developed for the central steam and coal depot concepts. A preliminary analysis of the central steam system indicates that it would substantially improve the economic comparison of direct coal combustion versus oil for small industrial users. The following example illustrates the improvements.

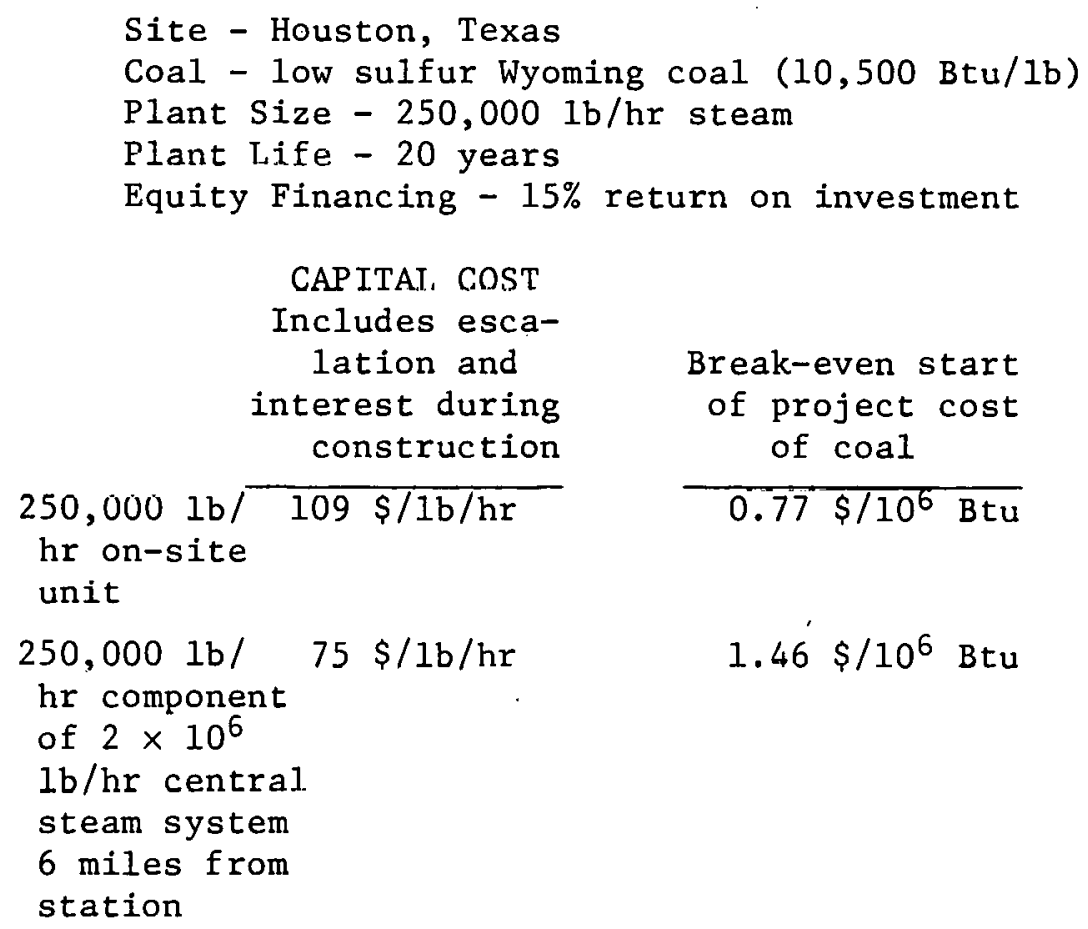

Break-even start of project cost of coal

$0.77 \$ / 10^{6} \mathrm{Btu}$

$1.46^{\prime} \$ / 10^{6} \mathrm{Btu}$ 


\subsection{Advanced Power Conversion Systems}

G. Samuel and A. P. Fraas*

\subsubsection{Contract Objective}

The objectives of this project are to review selected major advanced power conversion systems and to assess these systems on the basic R\&D status.

\subsubsection{Status Summary}

The purpose of this study is to examine the relative advantages and disadvantages of. the varlous advanced power conversion systems being considered by DOE. The prime emphasis is on the technological aspects of the concepts, especially experimental experience in the development of the critical components essential to the technical or economic feasibility of the concept.

The systems included in this study are conventional steam, conventional gas turbine, combined cycle, ceramic gas turbine, water-cooled gas turbine, coal-fired gas turbine, closed-cycle gas turbine, supercritical carbon dioxide, alkali metal Rankine, fuel cells, and MHD.

Draft reports covering all of the 11 systems and an overall summary report for the project have been completed. These reports have been submitted for peer review and comments.

Twelve dratt reports covering. these eleven subjects were sent tu DOE for review. Comments have been received on these reports and final reports are in preparation. Copies of four of the final reports are now being reviewed prior to publication.

\subsection{In Situ Coal Gasification \\ W. C. J1.rich and M. S. Edwards}

\subsubsection{Contract Objective}

The objective of this program is to provide technical and economic evaluations of candidate processes for the conversion of coal in situ to fluid products presently of interest. During FY 1977, technical and economic evaluations of the linked vertical well process applied to subbituminous coal were addressed. Three alternative end product configurations were considered - electricity, SNG, and syngas. In FY 1978, an evaluation is being conducted of an in situ facility for producing gasoline from methanol via the Mobil-M process.

\footnotetext{
*onsultant
} 


\subsubsection{Status Summary}

A preliminary overall block flow diagram for the in situ syngas-togasoline facility was completed. Process flowsheets for the various sections of the overall facility are currently being prepared. Material balance and equipment sizing calculations based on the process flowsheets are continuing.

A major design objective is to minimize pressure losses in the raw gas while it is being subjected to various treating processes necessary to prepare it for conversion to methanol. Minimizing pressure losses reduces the amount of energy required for compressing the gas to the pressure of the methanol synthesis loop ( 1500 psia). An existing ORNL heat exchanger design program is being adapted to help in the design of the large gas-to-gas heat exchangers needed for the facility.

Design and cost information for the methanol synthesis section of the facility is largely proprietary and is not available in the open 1iterature. Examples of the types of information needed on the methanol synthesis section are as follows:

- Compositions, flowrates, and conditions for feedstock and product streams, flowrate and heating value of purge gas streams, and approximate quantities and types of waste streams.

- Amounts and kinds of utilities consumed and generated.

- Capital and operating cost estimates.

To obtain this information for use in our report, a purchase requisition was submitted to our Purchasing Division. Bids are being solicited from the three U.S. licensees of the ICI (Imperial Chemical Industries) proprietary methanol process: Davy Powergas, Foster-Wheeler Corp., and Pullman-Kellogg Co.

\subsubsection{Open Items}

DOE review of the draft evaluation report, Process Designs and Economic Evaluations for the Linked Vertical Well In Situ Coal Gasification Process (ORNL-5341), is continuing. The report, which represents the culmination of our FY 1977 in situ coal gasification analyses studies, describes three conceptual plants designed for utilizing gas produced from a linked vertical well in situ coal gasification process and gives results of economic evaluations based on the designs. Final preparation will be concluded following receipt of DOE comments.

Approval of the revised work statement for FY 1978 transmitted to $\mathrm{DOE} / \mathrm{FE}$ on December 9, 1977 has not been received. 


\subsection{Coal Beneficiation}

S. P. N. Singh and G. R. Peterson

\subsubsection{Contract Objective}

The objective of this study is to provide technical and economic evaluations of currently used and potential coal beneficiation processes.

\subsubsection{Status Summary}

Project efforts culminated in a draft final report titled Survey and Evaluation of Current and Potential Coal Beneficiation Processes (ORNL/ TM-5953) which was completed in October and forwarded to DOE for review and comments. The report summarizes the technical evaluations of currently used coal benef1ciation techniques as well as several novel techniques.

We are attempting to arrange a meeting with DOE representatives to resolve their comments on the draft in preparation for final publication of the report.

\subsection{Gas Cleanup Studies}

M. S. Edwards

\subsubsection{Contract Objective}

The objective of the gas cleanup study is to collect information on the technology and economics of processes for the removal of impurities (principally hydrogen sulfide) from fuel gas streams. High- and lowtemperature cleanup processes will be reviewed.

\subsubsection{Status Summary}

The draft report ORNL/TM-6077, Selection of Candidate $\mathrm{H}_{2} \mathrm{~S}$-Removal Processes Applied to Low-Btu C'oal Gas, was sent to the Department of Energy on October 3, 1977. The report gives detailed prosess descriptinns and cost data for seven methods of removing $\mathrm{H}_{2} \mathrm{~S}$ from a low-Btu coalderived gas: MDEA, Benfield, Selexol, Sulfinol, Stretford, MERC Iron Oxide, and Molecular Sieve. Each of these processes was selected as representing a particular category of gas treating.

DOE comments on the draft report were received on February 8, 1978 and have been reviewed to determine changes that are needed in the report prior to publication. Some of the DOE comments raise questions which require further discussion, and a meeting with DOE representatives will be arranged to resolve these. 


\subsection{HYGAS Modeling}

J. P. Meyer, G. C. Frazier, J. W. Wells, and J. P. Belk

\subsubsection{Contract Objective}

The objective of this project is to develop a computer model of the HYGAS gasifier.

\subsubsection{Status Summary}

During the reporting interval, programming of the IG'L kinetic model for slow-rate gasification has been completed. Preliminary results obtained from the model show favorable agreement with those presented in the IGT publication, Preparation of a Coal Conversion Systems Technical Data Book (FE 1730-21), for the low pressure regime. In the future, comparisons over the entire spectrum of operating conditions will be undertaken.

Two limiting case approaches have been selected as a basis for modeling devolatilization phenomena. The first of these, rapid rate devolatilization, is based on the work of Anthony and Howard ${ }^{1}$ in which devolatilization is represented as an infinite number of parallel reactions having a continuous distribution of activation energies. For cases involving fine particles $(<50 \mu)$ and rapid heating rates $(>600 \mathrm{C} / \mathrm{sec})$, Anthony and Howard have obtained excellent correlations by this type of analysis. The other limiting case is based on slow devolatilization, which occurs when the rate of temperature rise is less than $10 \mathrm{C} / \mathrm{sec}$. Using available published data on product distribution and information on the cracking of coal liquids, it should be possible to characterize the product distribution resulting from the slow devolatilization step. By looking at the possible distributions that can occur at the extremes of the heating rate curve (slow rate vs rapid rate), it is hoped that it will be possible to bracket the range of devolatilization product compositions.

During the forthcoming month, work will commence on linking the current one-stage IGT kinetic model with an additional upper stage to model both the low and high temperature hydrogasification reactors as they exist in the HYGAS Pilot Plant. In addition, the kinetic step for rapid rate methane formation, as presented by Johnson, ${ }^{2}$ will be incorporated into the model.

\subsection{Liquefaction}

J. R. McWherter

\subsubsection{Contract Objective}

The objective of this project is to provide technical and economic evaluation of coal conversion liquefaction processes. Ralph M. Parsons 
Company is working under subcontract on the project with J. B. O'Hara as Project Manager. Major tasks included in the subcontract are: (1) a survey of liquefaction processes, and (2) a detailed review of high potential liquefaction processes.

\subsubsection{Status Summary}

Task 1. A review is continuing at ORNL of the data source book prepared by Parsons which summarizes the characteristics of 32 liquefaction processes.

Task 2. From the processes included in the survey, Parsons selected five high potential processes for more detailed considerations. These are: (1) a combined process for coal conversion to methanol followed hy catalyt1c conversion of the methanol to gasoline, (2) H-Coal process, (3) CSF, a donor solvent process, (4) Solvent Refined Coal (SRC) process, and (5) a process involving the Fischer-Tropsch approach. Parsons developed preliminary block flow diagrams, fixed capital investment estimates and economics for the five high potential processes selected.

Additional information was obtained on the SRC II process and Parsons is revising the process yields and fixed capital investment based upon this latest information.

\subsection{High Btu.Gas}

J. R. McWherter

\subsubsection{Contract Objective}

This subprogram is being analyzed under subcontract by the Scientific Design Company, Incorporated (SD) with A. S. West as Project Manager. The present work is divided into three phases as follows:

1. The objective of Phase $I$ is to provide technical and economic cvaluations of competing processes, conrepts and systems for the production of high Btu gas from coal.

2. The objective of Phase II is to monitor and analyze data from the HYGAS Pilot Plant.

3. The objective of Phase III is tn perform a technical and economical evaluation of the Battelle Agglomerating Ash Burner Process for the production of medium Btu fuel gas, synthesis gas and hydrogen from coal. 


\subsubsection{Status Summary}

Phase I. No additional work was done on this phase.

Phase II. An SD team of engineers is monitoring the operation of the HYGAS Pilot Plant in Chicago. The start of Test No. 70 was delayed because of mechanical difficulties and problems associated with cold weather and was not started until February 11, 1978. Smooth operation at high feed rates was not achieved until February 21,1978 . The run was terminated on February 24, 1978 because of the failure of the quench circulation pump.

A briefing was conducted in Washington, D. C. on February 8 by SD for the parties involved in the monitoring of the HYGAS Pilot Plant. Representatives of SD, IGT, DOE and ORNL attended. SD presented the information obtained in their effort to that date. One preliminary observation by SD was that clinker formation may be a function of the steam/oxygen ratio.

IGT representatives presented a number of modifications proposed for the pilot plant.

Phase III. A final design basis for the gasifier/combustor was received by $S D$ from Battelle. $S D$ is now in a position to complete the process flowsheets for the fuel gas study. As soon as these flowsheets are complete, equipment specifications will be developed and the economic evaluation work will be started.

\subsection{Comparative Cost Estimates of Five Coal Utilization Processes}

J. R. McWherter

\subsection{0 .1 Contract Objective}

The objective of this study is to determine consistent investment costs for four different coal utilization processes plus a convenclonal coal-fired power plant. The study will consider a high sulfur bituminous coal, such as an Illinois No. 6 used for a $500 \mathrm{MW}$ power plant. of the four coal conversion processes, two will consider scrubbing sulfur from the flue gases, the third will consider atmospheric fluidized bed combustion with simultaneous entrapment of sulfur by injection of lime, and the fourth will consider a coal beneficiation process coupled with flue gas scrubbing. This study is being conducted under subcontract by Chem. Systems, Inc., with L. H. Weiss as Project Manager.

\subsection{0 .2 Status Summary}

There is no new information available to report on this project which is nearing completion. 


\subsection{References for Section 8}

1. D. B. Anthony, J. B. Howard, H. C. Hottel, and H. P. Meissner, "Rapid Devolatilization and Hydrogasification of Bituminous Coal," Fuel 55, 121 (1976).

2. J. L. Johnson, "Kinetics of Bituminous Coal Char Gasification with Gases Containing Steam and Hydrogen," Advances in Chemistry, Series 131, ACS, Washington, D.C. (1974). 


\title{
9. FOSSIL ENERGY ENVIRONMENTAL PROJECT
}

\author{
C. R. Boston
}

\subsection{Stored Solids Study}

W. J. Boeg1y, Jr.

A 45-gal (imperial gal) drum of Cogas waste was air-freighted to ORNL. Analysis of this ash has been initiated. Paper work has been started to obtain 35 additional drums for lysimeter testing. This amount should be available for surface shipment during March. Similar amounts of waste have been requested from the Slagging Lurgi operation at Westfield, Scotland. This may also be shipped in March, 1978. Varying quantities of solid waste from six different pilot plants are now available at ORNL, along with various feed coals.

Arrangements have been initiated to obtain Ohio No. 9, Western Kentucky No. 9, Lower Freeport, and Shamokin, Pennsylvania anthracite. The Department of Energy has been performing coal grinding tests on these coals and can supply in two size types: coarse--95\% passing 16 mesh, and fine--70\% passing 200 mesh. We have requested from one to four $55-\mathrm{gal}$ drums of Ohio No. 9 (representative of feed coal to Conoco demonstration), and one 55-gal drum of the balance of the list. Coarse grind was requested as delivered from the mine, but underground samples were also requested for coal pile leaching studies. Four 55-gal drums of Wyodak coal have been requested on a purchase order but have not been delivered.

Two reports have received internal and DOE review and have been delivered to the ORNL Reproduction Department for publication. These reports are: "A Review of the Literature on Leachates from Coal Storage Piles," ORNL/TM-6186, and "Quarter1y Report - Experimental Study of Leachate from Stored Solids - Period July 1, 1977, to January 1, 1978," ORNL/TM-6304. An "Interim Analytical Report on the FEEP Stored Solids Task" was delivered to DOE/FE (H. T. Jones) for use in a paper to be presented at an American Chemical Society meeting in Anaheim, California, March 17, 1978.

Delivery of lysimeters still represents a potential delay in the stored solids task. However, the unavailability of waste has not made this a critical item at this time. Initial requests for estimates on four fiberglass lysimeters received no response from vendors and direct placement of a purchase order led to a ruling that the units were capital equipment.

Rebidding for concrete construction instead of fiberglass led to a delivery date in mid-March. These units should be available in time to receive waste shipments from England and Scotland. Thus, lysimeter installation should not delay the experimental program. Modified lysimeters for coal leaching are currently under construction at ORNL. 


\subsection{Environmental Monitoring Handbook (S. G. DeCicco)}

Activities this month centered on reviewing the Radian document for technical accuracy and general continuity of style with the ORNL Handbook. Editorial work continued on the remainder of the Handbook. The Summary chapter went through two rewrites and reviews. Discussions were held with Radian on February 27 to discuss the needed alterations.

\subsection{Technical Assistance}

\subsubsection{Interaction with Demonstration P1ant Contractors (S. G. DeCicco)}

Work continued on the Memphis, Light Gas \& Water (MLGW) demonstration project. On February 17 the task leader went to Washington, D. C., to review a justification for going sole source with Energy Impart Assnciates (EIA) as the environmental subcontractor. The document also included EIA's qualifications and a draft work statement for the proposed environmental monitoring program and environmental report (ER). Written comments were provided at the meeting and additional comments were sent via telefax on February 21. An ORNL team consisting of the task leader, an aquatic ecologist and terrestrial ecologist, visited the MLGW plant site on February 24. Representatives from MLGW escorted the team over the site and the surrounding area. An updated work scope prepared by EIA for the $E R$ and the environmental monitoring program was received on February 28.

Technical Assistance on the Grace/Ebasco demonstration project included a review of a work statement for the environmental task. This request was received on February 6 . Because of the general nature of the work scope the Task Leader reviewed the paper and sent written comments to DOE on February 10.

\subsection{Carryover Activities from FY 1977}

9.4.1 Environmental and Health Aspects of Disposal of Solid Wastes from Coal Conversion: An Information Assessment (H. M. Braunstein).

This document is receiving final in-house review and is now scheduled to go to the printer on April 15, 1978. The original target date was missed because the required in-depth review was not completed on schedule and because of higher priority assignments.

9.4.2 Environmental Considerations for Inclusion in PON's, RFP's, and ER's: Fossil Energy Demonstration Plant (M. S. Salk)

Final approval by DOE wae obtaincd and the document was published as ORNL/TM-6171. 


\section{MAGNETIC BENEFICIATION OF DRY PULVERIZED COAL}

D. M. Eissenberg, E. C. Hise, and M. D. Silverman

This program was initiated during FY 1977 using Advanced Power Systems Program Development funds.

\subsection{Objective}

The objective of this project is to develop and demonstrate a process for coal beneficiation by magnetic separation of pyrites and ash from dry pulverized coal.

\subsection{Status Summary}

10.2.1 Program Status. The Program Plan (189) is being reviewed by the Division of Solid Fuels Mining and Preparation. Visits were made to the Department of Energy (DOE) Coal Preparation and Analysis Laboratory (A. I.. Deurbrouck) and to DOE Headquarters (Bill Warnke) to discuss the program status. No new FY 1978 programs are being funded now, but the expectation is that the money will be released soon.

10.2.2 Separation Studies. Exploratory testing of the handling characteristics and magnetic susceptibility of coal from a power plant pulverizer effluent of a direct fired, pulverized coal furnace and retained in the sealed sample container. The coal is from various seams local to Oak Ridge, Tennessee. The pulverizer product is transported in about twice its weight of air at $200^{\circ} \mathrm{F}$ and is typically $70 \%<200$ mesh and $100 \%$ $<60$ mesh.

A number of 5 to $10 \mathrm{~g}$ samples were qualitatively tested in the Frantz Isodynamic Separator at various angles and feed rates. The material appeared to flow freely and consistently and to exhibit a relatively high degree of magnetic susceptibility. As opposed to laboratory ground and sized samples of coal, there was no obvious difference in appearance between the magnetic and nonmagnetic fractions. A $20 \mathrm{~g}$ sample was separated at settings that yielded 14\% magnetic fraction and was submitted for chemical analyses.

Work will continue separating and analyzing pulverizer run coal from on- and off-site power plants. Samples will be separated both as run and in sized fractions to determine whether there is any significant difference in the separability of distribution of magnetics as a function of size.

10.2.3 Auburn University Subcontract. The draft report was not received this month. A paper summarizing the results of this work was accepted for presentation at the INTERMAG Conference (Florence, Italy) in May 1978. 
11. ATMOSPHERIC FLUIDIZED BED COMBUSTION DEMONSTRATION PLANT

C. B. Smith and J. E. Jones Jr.

\subsection{Engineering Support}

W. H. Fleischman, J. W. We1ls, H. A. Mitche11, and S. E. Hamblen

\subsubsection{Project Status}

This project is proceeding on a low level until the additional design studies that are to be performed by the three major boiler manufacturers for DOE and TVA provide information on lie potential impact of the proposed new EPA eluission regulationo on the relative economics of the AFBC. proress for utility applications.

\subsubsection{Program Opportunity Notice (PON) Preparation}

No additional work is being done on the PON pending resolution of the project status.

\subsubsection{Support Studies}

Technical support study work continued on developing the heat transfer surfacing code, determining steam cycle efficiencies for the three TVA design study demonstration plants and determining estimated weights of the three demonstration plant steam generators. Cust estimate is to bo developed for major equipment and subsystems for comparisons to the design atudy eetimates.

\subsection{Technology Assessment}

M. Siman-Tov, H. D. Cochran, T. G. Godfrey,

R. E. Kuhlman, M. E. Lackey, and G. Samuels

Contacts have been made witli a number of organizations involved in AFBC to discuss the technology status as related to the demonstration plant project. As a result, two visits took place during the month of February--one to MIT in Boston and the other to TVA in Chattanooga. A visit to EPA in Research Triangle was tentatively scheduled for March 27.

The visit to MIT was informative and included a round-table discussion of general questions (which were prepared and distributed before the meeting started), a visit to a 2 by $2-\mathrm{ft}$ FBC facility and a 4 by $4-\mathrm{ft}$ turbulent flame facility, individual discussions on specific AFBC subjects and demonstration of the computerized data base application. 
The visit to TVA was informative and helped to clarify TVA's position on the demonstration plant. Mr. Falkenberry feels there is the need to accelerate the demonstration plant program and requested cooperation between TVA and ORNL technical divisions. Bill McKinney reviewed the TVA program. TVA has received draft final reports from the three boiler manufacturers and is evaluating them. TVA intends to continue studies on the project, including site selection and effects of the proposed new source performance standards of the EPA.

Contacts with other facilities and organizations are in progress and we hope to conclude our visits during April.

Additional work has been done in updating the AFBC library and completing the comparative matrix of demonstration plant design and operating parameters based on $\mathrm{FW}, \mathrm{CE}$, and $\mathrm{B} \& \mathrm{~W}$ designs. 
THIS PAGE

\section{WAS INTENTIONALLY \\ LEFT BLANK}


ORNL/TM-6329

INTERNAL DISTRIBUTIION

\author{
1. S. I. Auerbach \\ 2. M. Bender \\ 3. C. R. Boston \\ 4. C. H. Brown \\ 5. G. H. Burger \\ 6. J. E. Campbel1 \\ 7. D. A. Canonico \\ 8. J. A. Carter \\ 9. B. R. Clark \\ 10. H. D. Cochran, Jr. \\ 11. E. Copenhaver \\ 12. K. E. Cowser \\ 13. R. M. Davis \\ 14. D. G. Doherty \\ 15. M. S. Edwards \\ 16. D. M. Eissenberg \\ 17. J. L. Epler \\ 18. D. E. Ferguson \\ 19. L. M. Ferris \\ 20. R. C. Forrester III \\ 21. W. Fulkerson \\ 22. E. L. Fuller \\ 23. W. R. Gambill \\ 24. R. B. Gammage \\ 25. D. A. Gardiner \\ 26. C. W. Gehrs \\ 27. R. W. Glass \\ 28. T. G. Godfrey \\ 29. W. L. Greenstreet \\ 30. M. R. Guerin \\ 31. C. W. Hancher \\ 32. L. A. Harris \\ 33. S. E. Herbes \\ 34. J. R. Hightower \\ 35. R. S. Holcomb \\ 36. J. M. Holland \\ 37. J. M. Holmes \\ 38. J. K. Huffstetler \\ 39. G. R. Jasny, $Y-12$ \\ 40. R. L. Jolley \\ 41. J. E. Jones Jr. \\ 42. O. L. Keller \\ 43. R. T. King \\ 44. J. A. Klein \\ 45. W. R. Laing \\ 46. R. S. Livingston \\ 47. R. E. MacPherson \\ 48. A. P. Malinauskas
}

49. G. B. Marrow

50. C. J. McHargue

51-60. L. E. McNeese

61. J. R. McWherter

62. J. E. Mrochek

63. P. Nettesheim

64. B. Niemann

65. L. C. Oakes

66. G. E. Oswald

67. G. R. Peterson

68-69. T. W. Pickel

70. H. Postma

71. D. E. Reichle

72. C. R. Richmond

73. B. R. Rodgers

74. M. W. Rosenthal

75. R. H. Ross

76. T. H. Row

77. W. L. Russe11

78. R. Salmon

79. G. Samuels

80. C. D. Scott

81. D. S. Shriner

82. W. D. Shults

83. S. P. N. Singh

84. C. B. Smith

85. G. P. Smith

86. I. Spiewak

87. R. L. Spore

88. J. B. Storer

89. R. A. Strehlow

90. H. E. Tramme11

91. D. B. Trauger

92. W. C. Uirich

93. P. R. Vanstrum

94. J. S. Watson

95. J. R. Weir

96. P. R. Westmoreland

97. L. V. Wilson

98. E. L. Youngblood

99. C. S. Yust

100. S. Alpert (Consultant)

101. H. Beuther (Consultant)

102. M. Semchyshen (Consultant)

103. H. W. Sternberg (Consultant)

104. C. Streed (Consultant)

105. Patent office

106. Lab. Records-RC 
107-112. Lab. Records

113-115. Central Research Library

116. Document Reference Section

EXTERNAL DISTRIBUTION

DOE-Oak Ridge Operations

117. Research and Technical Support Division

DOE-Denver Project Office, Suite 211, 1075 S. Yukon Street, Lakewood, CO 80226

118. A. A. Hagen

DOE-FE, Washington, DC

119. W. Bakker

120. E. K. Bastress

121. J. D. Batchelor

122. J. Belding

123. T. Beresovski

124. L. M. Burman

125. E. L. Burwell

126. E. L. Clark

127. N. P. Cochran

128. R. C. Corey

129. T. Cox

130. C. W. D1 Bella

131. J. Furst

132. H. Frankel

133. S. I. Freedman

134. D. Garrett

135. W. S. Harmon

136. H. Jones

137. L. Joseph
138. L. Kindley

139. C. W. Knudsen

140. T. K. Lau

141. W. G. McDaniel

142. C. Miller.

143. M. Neuworth

144. E. S. Pierce

145. H. E. Poda11

146. J. L. Powe 11

147. M. Reilly

148. J. Shen

149. A. P. Sikri

150. J. Smith

151. D. K. Stevens

152. W. E. Warnke.

153. J. W. Watkins

154. H. L. Weisenfeld

155. D. O. Webb

156. P. R. Wieber

DOE-Environment, Washington, DC

157. N. F, Barr

158. R. M. Jimeson

159. W. E. Mott

160. R. W. Wood

161. P. Niıhame?

Department of Housing and Urban Development, 451 7th St., S.W., Washington, DC 20410

162. G. S. Le1ghton

163. J. H. Rothenberg 
University of Kentucky, Institute for Mining and Materials Research,

213 Bradley Hall, Lexington, KY 40506

164. Theresa Wiley, Institute Librarian

165. 0. J. Hahn

166. J. K. Shau

National Science Foundation, 1800 G Street, N. W., Washington, DC 20550

167. Robert Rabin

168. Charles B. Sedman, U.S. Environmental Protection Agency, Research Triangle Park, NC 27711

169. N. S. Boodman, Section Supervisor, U.S. Stcel Corporation Applied Research Laboratory, 125 Jamison Lane, Monroeville, PA 15146

170-181. ERDA Pittsburgh Energy Research Center, U.S. Energy Research and Development Administration, Attention: Director for J. P. Barreca, 4800 Forbes Ave., Pittsburgh, PA 15213

182-187. The Director, Morgantown Energy Research Center, P.0. Box 800, Morgantown, WV 26506

188. Tetra Tech, Inc., 1911 N. Ft. Myer Drive, Suite 601, Arlington, VA 22209, Attention: Walter McGough, Jr.

189. Cameron Engineers, Attn: Gary L. Baughman, 1315 South Clarkson St., Denver, CO 80213

190. Steven R. Smith, Tennessee Valley Authority, 1230 CUBB-C, Chat tanooga, TN 37401

191. Manville J. Mayfield, Tennessee Valley Authority, 1320 CUBB-C, Chattanooga, TN 37401

192. Randy M. Cole, Tennessee Valley Authority, 1320 CUBB-C, Chat tanooga, TN 37401

193. Jack L. Gregory, Project Manager, TRW Energy Systems, 7600 Colshire Drive, McClean, VA 22101

194. F. N. Peebles, Dean of Engineering, University of Tennessee, Knoxville, TN 37916

195. Frank P. Baranowski, Mechanical Technology Incorporated Cryslal Square 4, Suite 310, Jefferson Davis Highway, Arlington, VA 22202

196. William C. Corder, Bechtel National, Inc., Engineers-Constructorc, Fifty Beale Street, Post Office Box 3965, San Francisco, CA 94119

197-223. Technical Information Center, DOE 